RUSSIAN-AMERICAN RELATIONS

125

FROM 1834 TO 1845

by

Gerald Irwin Leonard

Approved by Committee:
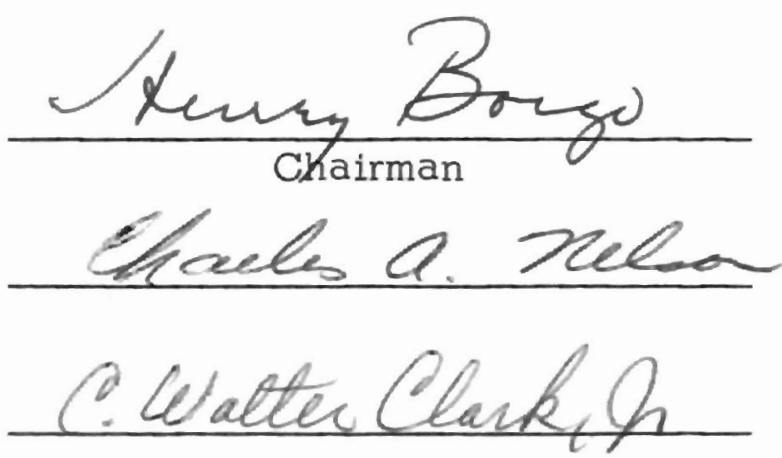

$\frac{\text { Care L. Aampild }}{\text { Dean of the Graduatepivision }}$ 


\title{
RUSSIAN-AMERICAN RELATIONS
}

FROM 1834 TO 1845

\author{
A Thesis \\ Presented to \\ The Graduate Division \\ Drake University
}

In Partial Fulfillment

of the Requirements for the Degree

Master of Arts in History

by

Gerald Irwin Leonard

August 1966 
TABLE OF CONTENTS

CHAPTER

PAGE

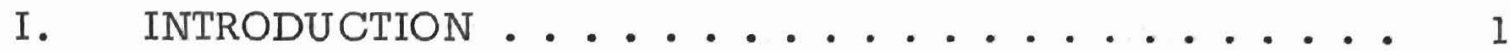

II. BACKGROUND OF DISPUTE OVER NORTHWEST COAST . . . . 7

III. REOPENING OF THE TREATY OF 1824. . . . . . . . 23

IV. AFTERMATH AND RESUITS OF THE NORTHWEST COAST

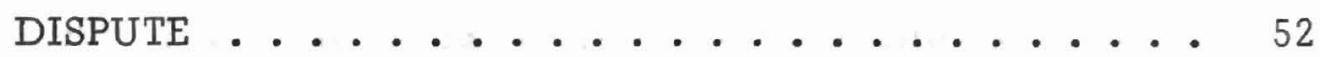

V. OTHER RUSSIAN-AMERICAN CONTACTS ......... 64

VI. SUMMARY AND CONCLUSIONS . . . . . . . . 83

BIBLIOGRAPHY . . . . . . . . . . . . 88

APPENDIX . . . . . . . . . . . . . . . 92 


\section{INTRODUCTION}

The purpose of this thesis is to examine the state of RussianAmerican relations between the years 1834 to 1845 . These dates were selected because they coincided with the beginning and approximate end of the controversy between Russia and the United States over the northwest coast of North America, caused by the expiration of the fourth article of the treaty of 1824 .

Russian-American relations during those years have been largely ignored by historians. Pauline Tompkins wrote of the years following the signing of the Russian-American Commercial Treaty of 1832: "Thereafter for approximately two decades the American and Russian governments had few contacts." 1 William Appleman Williams completely ignored this period in his book on Russian-American relations. 2 Thomas A Bailey said: "Diplomatically speaking, the years from 1832 to $1848, \ldots$ are barren in Russo-American relations. " 3

lPauline Tompkins, American-Russian Relations in the Far East (New York: The Macmillan Company, 1949), p. 10.

${ }^{2}$ William Appleman Williams, American Russian Relations, 1781-1947 (New York: Rinehart \& Co., Inc., 1952).

${ }^{3}$ Thomas A. Bailey, America Faces Russia (Ithaca, New York: Cornell University Press, 1950), p. 50. 
The controversy over the northwest coast was the only important diplomatic dispute between the two nations at this time. This dispute constitutes the main subject of this thesis, but not the only one. Relations between nations consist of more than diplomacy. A discussion of Russian-American trade has been included. Also, it was at this time that Russia turned to the United States for aid in building railroads and steamships. Similar conditions and transportation needs in the United States made this only natural. A brief discussion of some of the diplomats of the two countries, active at this time, concludes the list of topics encompassed by this thesis. No attempt has been made to cover all of the contacts which took place between Russians and Americans during the years being considered.

During the 1830's and 1840's, Russia and America were more alike and, at the same time, more different, than any of the other major countries of the world. Both were large nations in the process of development, but with systems of government which were complete opposites. One person who noticed both the similarities and the dissimilarities was a young Frenchman, Alexis de Tocqueville, who visited the United States in 1831 and 1832. He wrote:

There are at the present time two great nations in the world, which started from different points, but seem to tend towards the same end. I allude to the Russians and the Americans. Both of them have grown up unnoticed; and whilst the attention of mankind was directed elsewhere, they have suddenly placed themselves 
in the front rank among the nations, and the world learned their existence and their greatness at almost the same time.

All other nations seem to have nearly reached their natural limits, and they have only to maintain their power; but these are still in the act of growth. All the others have stopped, or continue to advance with extreme difficulty; these alone are proceeding with ease and celerity along a path to which no limit can be perceived. The American struggles against the obstacles which nature opposes to him; the adversaries of the Russian are men. The former combats the wilderness and savage life; the latter, civilization with all its arms. The conquests of the American are therefore gained by the plowshare; those of the Russian by the sword. The Anglo-American relies upon personal interest to accomplish his ends and gives free scope to the unguided strength and common sense of the people; the Russian centres all the authority of society in a single arm. The principal instrument of the former is freedom; of the latter, servitude. Their starting-point is different and their courses are not the same; yet each of them seems marked out by the will of Heaven to sway the destinies of half the globe. ${ }^{1}$

During the years following de Tocqueville's uncanny prediction, the American public was constantly exposed to tales of Russian barbarism and cruelty. Although the truth of many of these reports was suspect, they had much influence on public opinion in the United States. Anger against the Russians caused by the suppression by Tsar Nicholas I of the Polish revolt of 1830 , continued for many years. Russia's war with the Circassian tribes from 1839 to 1845 also stirred some American feeling against the Russians.

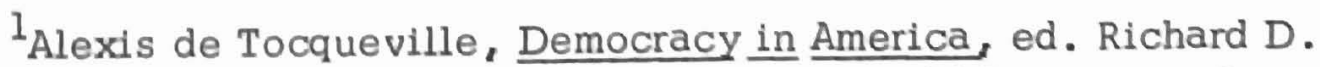
Heffner (New York: The New American Library of World Literature, Inc. , 1956), pp. 19-20. 
From a diplomatic standpoint, the United States, during this period, was represented in Russia, for the most part, by inferior men. St. Petersburg was unhealthy because of its climate, was very far away and was considered an ideal place to which the administration could banish political troublemakers. Most American representatives stayed there only a short time. ${ }^{1}$

In spite of all this, relations between the two countries were remarkably good. During the years considered here, there were a few conflicts of interest between the United States and Russia. There were, in fact, matters in which they shared a common interest. Throughout the nineteenth century, Russia cultivated American friendship in order that the two countries might present a common front against the power of Great Britain. 2

At no time did ideology interfere with this friendship even though the systems of government of the two nations were totally different, even more so than at the present time. When the United States and Great Britain came close to war over the McLeod affair in 1841 , the Russian government offered to help mediate so that a peaceful solution might be reached rather than have American strength wasted in a

\footnotetext{
${ }^{I_{\text {Bailey, }}}$ op. cit., p. 46 .

${ }^{2}$ williams, ㅇp. cit. , p. 4.
} 
useless war. 1

George M. Dallas, while minister to Russia, recorded the following entry in his diary regarding a conversation with Nicholas I:

I told him that my attention to the subject [of RussianAmerican relations] had produced a conviction that our highest interests as a nation were identified with those of Russia. "Not only are our interests alike," said he [Nicholas], "but (with emphasis in his tone) our enemies are the same." 2

Dallas' predecessor, William Wilkins, had expressed a similar view when he wrote:

If any government, in the situation of that of Russia, can be supposed to entertain sentiments of national partiality, I should be inclined to think, that there are directed towards us sentiments of more general good will--that we are viewed with a much more favorable eye--than either of the great powers [Great Britain and France] I have just named. 3

American diplomats in Russia found even the best-educated of Russians to be very ignorant of actual conditions in America. 4 One Russian who did study the United States with a critical eye, although

${ }^{1}$ Bailey, op. cit. , p. 50 .

${ }^{2}$ George Mifflin Dallas, Diary of George Mifflin Dallas, ed. Susan Dallas (Philadelphia: J. B. Lippincott Co., 1892), p. 209.

${ }^{3}$ National Archives and Records Service, Despatches from United States Ministers to Russia, 1808-1906 (Washington: National Archives Microfilm Publications, 1953), XIII, No. 4, Wilkins to Forsyth, Jan. 15/27, 1835. This source will hereafter be cited as Despatches.

${ }^{4}$ Alexandre Tarsaidze, Czars and Presidents (New York: McDowell, Obolensky, Inc., 1958), p. 116. 
he never actually went there, was Alexander Pushkin. His opinion was not a favorable one:

To our surprise, we discovered within democracy a repulsive cynicism, cruel prejudices and intolerable tyrannies. Everything noble, everything that uplifts the human soul, is being suppressed by a kind of egotism and a passion for comfort [italics in the original]. The majority brazenly suppresses society. Despite the cry of liberty, the slavery of the negroes continues. Not having nobility, the snobbishness of the people is surprising. The politicians show only greed and jealousy and are ingratiating in their efforts to please the mighty voters. There are contradictions to all the established rules of society. The rich man puts on a torn coat when he goes into the street in order not to insult the proud poor; yet he secretly despises them and is despised by them. Such is the picture of the United States recently presented to us. I

Opinions such as the one given here, had little effect on the course of relations between the two countries. The purpose of this thesis is to examine some of the more important events and contacts which affected relations between them.

${ }_{\text {Ibid. }}$ p. 117. 
CHAPTER II

\section{BACKGROUND OF DISPUTE OVER NORTHWEST COAST}

Vitus Bering, while on his second expedition in the service of Russia in the North Pacific in 1741, made known the valuable fur resources of the region, and, although he died on the return voyage, the expedition returned with large quantities of valuable furs. This led to the organization of many private expeditions in search of furs. In a short time, permanent settlements were established, forts and trading posts built, and many rival Russian companies competed with each other for furs. 1

The Russian-American Fur Company was the result of a merger of some of these independent trading associations. The most powerful of these was the Shelikov United Trading Company founded by Gregory Shelikov, a Siberian merchant who had been engaged in the fur trade since the early 1780's. Because his trade was being interfered with by the independent fur traders, he tried to secure an imperial grant of exclusive trading privileges in America and the Aleutian Islands.

Shelikov was successful. An imperial ukaz, issued in July, 1799, organized the Russian-American Fur Company and granted it, for a

${ }^{1}$ Fur Seal Arbitration: Proceedings of the Tribunal of Arbitration at Paris (Washington: Government Printing Office, 1895), II, 21-25. 
period of twenty years, a monopoly of the trade and exclusive jurisdiction over the northwest coast of North America north of fifty-five degrees north latitude. The company also had the right to occupy new lands on either side of that line if they were not already occupied by another nation. The company had the power to exercise all functions of government in the area under its control. 1

The headquarters of the company was located in St. Petersburg, and many Russian nobles and members of the imperial family bought shares in the company. These people were interested in seeing that the imperial government looked upon the activities of the company with favor. ${ }^{2}$

The company paid no rent or royalties to the government, but, as its trade consisted chiefly of trading furs in exchange for Chinese tea, the government received large sums from duties collected on such tea when it was brought into Russia. ${ }^{3}$

${ }^{1}$ Proceedings of the Alaska Boundary Tribunal: Case of the United States (Washington: Government Printing Office, 1903), Appendix, p. 20. Hereafter, the above source will be cited as Alaska Boundary Tribunal, Volume I. The appendix of this volume will be cited as Volume II. The volume titled Counter Case of the United States will be cited as Volume III. The appendix of that volume will be cited as Volume IV.

\section{${ }^{2}$ Ibid.}

${ }^{3}$ Fur Seal Arbitration, II, 37. 
Heavy obligations were also imposed upon the company. It was compelled, at its own expense, to carry on government, and to maintain courts, the church and a small military force. The directors of the company appointed a chief manager, Alexander Baranoff, who had absolute power within the territory under the company's jurisdiction. Reports of the company's transactions were submitted to the minister of the interior at first, and, later, to the minister of finance. 1

The company built a fort at Sitka in 1799, but, in 1802 the fort was destroyed and the garrison massacred by the Kolash, the local natives who were noted for their ferocity. The Russians accused American traders of supplying firearms and munitions to the Kolash. ${ }^{2}$ Another fort was constructed there in 1804 and was named New Archangel. 3

Although the 1799 ukaz prevented other Russian traders from interfering with the trade of the Russian-American Company, it did not prevent American vessels from trading with the natives. American traders secured a large proportion of the furs sold by the natives and made such large profits that the number of American vessels in the area

$1_{\text {Ibid.. II, } 37 .}$

${ }^{2}$ Victor J. Farrar, "The Background of the Purchase of Alaska," Washington Historical Quarterly, XIII (April 1922), 93.

${ }^{3}$ Alaska Boundary Tribunal, I, 6. 
constantly increased after 1790.1

The American minister to Russia, Henry Middleton, in a confidential memoir sent to the United States State Department in 1823, wrote:

... from the year 1804, the Russians could collect as many as eight thousand otters' skins annually, in the bay of Sitka, if they had the means of excluding the Americans from this trade, whilst at that time they only took from thence about three thousand. ${ }^{2}$

In 1808, Count Romanzov, minister of foreign affairs and of commerce, complained to the charge' d'affaires of the United States in St. Petersburg that American traders were supplying the natives with firearms and powder and that much harm had come from this practice. Mr. Daschkov, the Russian charge' d'affaires in Washington, made a similar protest in 1810. He asked that the American government prohibit, by law or treaty, its citizens from trading with the natives of the northwest coast and to confine their business to the Russian settlements located there. Nothing was done at this time because Daschkov was not empowered to fix a boundary within which such a law should operate. 3

As the time for the expiration of the charter of the RussianAmerican Company approached, its affairs became a matter of concern

$1_{\text {Ibid. , I, 6-7. }}$

${ }^{2}$ Ibid., II, 61.

${ }^{3}$ Ibid. , II , 63. 
to the Russian government. Plans were formulated to increase the prosperity of the company and to secure its monopoly of the trade. Since the company's chief cause of difficulty was the presence of American trading ships, the Tsar, on September 16, I 1821, is sued his famous ukaz for the benefit of the company. It read in part:

Sect. 1. The pursuits of commerce, whaling and fishery and of all other industry on all islands, ports and gulfs, including the whole of the north-west coast of America, beginning from Behring's Straits to the 5 lst degree of northern latitude, also, from the Aleutian islands to the eastern coast of Siberia, as well as along the Kurile islands from Behring's Straits to the south cape of the island of Urup, viz. to the $45^{\circ} 50^{\prime}$ northern latitude, are exclusively granted to Russian subjects.

Sect. 2. It is, therefore, prohibited to all foreign vessels, not only to land on the coasts and islands, belonging to Russia, as stated above, but also, to approach within less than an hundred Italian miles. The transgressor's vessel is subject to confiscation along with the whole cargo. ${ }^{2}$

On September 25, 1821, another ukaz renewed the privileges of the Russian-American Company for an additional twenty years. It differed from the ukaz of 1799 in that it extended the southern limit of the company's territory from fifty-five degrees southward to fifty-one

${ }^{1}$ All dates referred to are New Style unless otherwise indicated.

${ }^{2}$ Theodore Lyman, Jr. , The Diplomacy of the United States, 1778-1827 (second edition; Boston: Wells and Lilly, 1828), II, 287-88. 
degrees north latitude. ${ }^{I}$ A Russian fleet was sent to enforce the provisions of the ukaz of September 16.

Under the terms of the Convention of 1818 between the United States and Great Britain, these two nations had joint occupation of the territory north of forty-two degrees to a line yet to be determined. Therefore, both countries were provoked by the Tsar's ukaz. 2

On February 11, 1822, Pierre de Poletica, the Russian minister in America, sent a copy of the ukaz to Secretary of State John Quincy Adams. Adams expressed surprise at the broad Russian claims and asked Poletica if he were able to give the grounds on which the claims were based. An excerpt from Poletica's reply, dated February 28 , 1822, said:

In 1728 the celebrated Capt. Behring made his first voyage. The recitals of his discoveries attracted the attention of the government, and the Empress Anne, intrusted to Capt. Behring (1741), 3 a new expedition in these same latitudes. She sent with him the academicians Gamelin, Delisle, de la Croyere, Muller, Steller, Fisher, Krasilnicoff and others, and the first chart of these countries, which is known, was the result of their labours, published in 1758. Besides the strait, which bears the name of the chief of this expedition, he discovered a great

\section{${ }^{1}$ Alaska Boundary Tribunal, I, 10-11.}

${ }^{2}$ Dexter Perkins, The Monroe Doctrine, 1823-1826 (Harvard Historical Studies, Vol. XXIX. Cambridge: Harvard University Press, 1932), p. 8 .

${ }^{3}$ This was the year in which Behring sailed; Empress Anne had died in 1740 . 
part of the islands, which are found between the two continents; cape or mount St. Elias, which still bears this name, upon all the charts, was so called by Capt. Behring, who discovered it on the day of the feast of this saint, and his second captain Tschirikoff, pushed his discoveries as far as the 49th degree of north latitude. If the imperial government had, at the time, published the discoveries, made by the Russian navigators after Behring and Tschirikoff,. . . no one would refuse to Russia the right of first discovery, nor could any one deny her that of first occupation. 1

Poletica went on to explain that the ukaz had no hostile intention but was directed only against those who interfered with the rights of the Russian-American Company and who furnished arms and munitions to the natives. 2

Adams refused to accept the Russian claims and sent a vigorous protest. The Russian government saw that its claims were untenable and sent Baron de Tuyll to Washington in hopes of settling the matter. Meanwhile, the Russian fleet was ordered not to enforce the ukaz too strictly.

Middleton was not told of Tuyll's mission. Adams had given him instructions to make sure that the Russian government understood that the United States would not consider itself bound by the Tsar's ukaz. 3

On July 24, 1822, Middleton read to Count Capodistrias, the

${ }^{1}$ Lyman, op. cit. , II, 290.

${ }^{2}$ J. C. Hildt, Early Diplomatic Negotiations of the United States with Russia Johns Hopkins University Studies in Historical and Political Science, Series XXIV, Nos. 1-2. Baltimore: The Johns Hopkins Press, 1906), pp. 16I-62.

${ }^{3}$ Ibid., pp. 164-66. 
Russian foreign secretary, a note which he said he intended to give to Count Nesselrode. ${ }^{1}$ The note said that war was likely between the United States and Russia unless the Russian government refrained from putting the ukaz into effect:

A careful perusal of the correspondence which has recently been exchanged at Washington. . . cannot fail to show that a state of war between the two powers exists already, owing to the principles that have been avowed on both sides. Nothing is lacking to make this complete except a declaration or acts of violence, which latter cannot be long in coming, unless precautionary measures be at once taken. ${ }^{2}$

Capodistrias persuaded Middleton not to give the note to

Nesselrode as the Tsar already realized that the matter had gone too far. ${ }^{3}$

Capodistrias then told Middleton that Baron Tuyll had been sent to Washington with full powers to settle the dispute, and that meanwhile, the American government ought to forbid its citizens from trading in the disputed area. Middleton replied that this could not be done without admitting Russia's exclusive rights and that until those rights were proven, the American government had no authority to prohibit

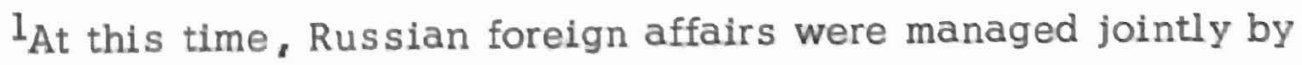
Nesselrode and Capodistrias.

${ }^{2}$ Fur Seal Arbitration, II, Appendix, p. 138.

${ }^{3}$ Benjamin Platt Thomas, Russo-American Relations, 1815-1867 (Johns Hopkins University Studies in Historical and Political Science, Series XIVIII, No. 2. Baltimore: The Johns Hopkins Press, 1930), p. 44. 
its citizens from exercising their rights within the law. ${ }^{1}$

Baron Tuyll arrived in Washington in April, 1823. He wrote Secretary of State Adams that the Emperor desired to have the dispute solved by friendly negotiation. He said that the British ambassador at St. Petersburg had been furnished with full powers to accomplish this and asked that Mr. Middleton also be furnished with the necessary authority to reach an agreement to end the controversy. Adams agreed to this request. 2

It had been proposed that the United States and Great Britain negotiate jointly with the Russians. Sir Charles Bagot, representing Great Britain, was in St. Petersburg ready to begin conversations with the Russians. On December 17, 1823, in London, George Canning, the British foreign secretary, received the American minister, Richard Rush, in order to hear America's views on this question before sending Bagot instructions. He was amazed to learn from Rush that the United States seemed to wish to guarantee Russia against British expansion north of fifty-five degrees and to assume the line of fifty-one degrees as the boundary between American and British territory. This would confine the British to the narrow strip between fifty-one and fifty-five degrees. Even this would be in jeopardy with the Russians claiming

$$
\begin{aligned}
& { }^{1} \text { Hildt. , op. it. , pp. 166-67 } \\
& { }^{2} \text { Ibid. , pp. 167-68. }
\end{aligned}
$$


an exclusive monopoly to fifty-one degrees.

When, a few days later, President Monroe's message with its non-colonization principle (i.e., the Monroe Doctrine), reached Canning, he told Rush that since Great Britain could not agree with the principle proclaimed by Monroe, it would be better if each country reached a settlement with Russia separately. 1

Not until February, 1824, did Middleton learn that he was to negotiate alone. Poletica represented the Russian government although Nesselrode often took part in the discussions. ${ }^{2}$

At the start of the negotiations, Middleton proposed the following points:

(1) mutual freedom of navigation and trade in every part of the Pacific.

(2) that subjects of neither country should land at establishments of the other without first securing permission from the local authorities.

(3) that the United States should neither authorize nor allow its citizens to establish settlements north of the fifty-fifth parallel, and Russia should, in like manner, enjoin her citizens from settling south of that line. ${ }^{3}$

${ }^{1}$ J. H. Powell, Richard Rush, Republican Diplomat, 17801859 (Philadelphia: University of Pennsylvania Press, 1942), pp. 168-69.

${ }^{2}$ Thomas, op. it., pp. 44-45.

3 Ibid. , p. 45. 
As to the first point, Poletica said that Russia relinquished the right to declare any part of the Pacific as a closed sea. But as to the second point, however, he would not agree to the free admission of American vessels to all parts of the coast nor to free trade with the natives. 1

Middleton then made an alternative proposal. This was that the entire northwest coast should be free and open to the citizens of either country for a period of ten years or until an agreement was reached setting definite boundaries.

Nesselrode attempted to change this so that the period of time would be only five years and that it would apply only to free and open fishing. Under his plan no trade would be allowed. ${ }^{2}$

Middleton then proceeded to present a paper challenging the strength and legality of Russia's claims to territory on the northwest coast. The Russians, rather than have this question raised, agreed to the original proposal on the condition that trade in firearms, munitions and alcohol be prohibited. Middleton agreed to this after inserting a provision that this could never be used as a pretext for the search or detention of American vessels. 3

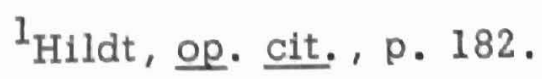

${ }^{2}$ Ibid.

${ }^{3}$ Ibid. , pp. $183-85$. 
Middleton's third proposal had stated that no settlements were to be made north of fifty-five degrees by the Americans nor south of that line by the Russians. But because the Russians already had a settlement at Port Bacurelli, south of fifty-five degrees, and did not want to give it up, Middleton agreed to change the line to fifty-four degrees forty minutes. 1

At last the treaty, the first between the United States and Russia, was signed by Middleton, Poletica and Nesselrode on April 17, $1824 .^{2}$

Both this treaty and a similar one signed the next year with Great Britain placed severe restrictions on the Russian-American Company. The company's hopes of expanding its trading activities were ended along with any chance of outlawing the trade in firearms and liquor. Barring foreign traders from the Russian colonies had been difficult before the treaties had been signed; it would now be a total impossibility. This was bound to result in severe financial setbacks for the company and, also, increased tension between the Russians and the natives, who would now be in frequent contact with the British and Americans. ${ }^{3}$

\section{Thomas, op. cit., p. 45.}

2 See Appendix for complete text of treaty.

${ }^{3}$ Anatole G. Mazour, "The Russian-American and Anglo-Russian Conventions, 1824-1825: An Interpretation," Pacific Historical Review, XIV (September 1945), 308. 
Officials of the Russian-American Company strongly protested the signing of the treaties. One appeal to the minister of finance argued that the influx of profiteers which would result from the treaties would form an irresistable competitive block against the Russians. It was further argued that these profiteers would be in direct contact with the natives, the result being that the company would eventually face a rebellion by the native population.

Among the protesters was the future Decembrist, Dimitry Zavalishin:

He bitterly criticized the policy of his government which he thought bordered on levity; its maudlin promises, he predicted with a high degree of accuracy, particularly with respect to the convention with the United States, would eventually result in the total liquidation not only of Fort Ross in California, but of all Russian possessions in the New World, including Alaska. 1

Nesselrode defended the treaty by saying that it confirmed to Russia rights which had been called into question and that those rights had now been acknowledged by those who were in a good position to dispute them if they so desired. He also pointed out that the treaty forbade trade in firearms and liquor, something which would be very difficult for Russia to do unilaterally. In regard to the controversial fourth article four he said:

That it is not less advantageous to Russia to be assured by a mutual and amicable convention that after the expiration of ten

I Ibid., p. 309 . 
years the subjects of the United States of America will abstain entirely from visiting the waters of the North American coast beyond $54{ }^{\circ} 40^{\prime}$ and from fishing and from trading there with the native inhabitants; for, on the one hand, it would be impossible to suppose that the States would voluntarily consent to such a concession without any compensation whatever, and, on the other hand, all the wishes expressed to the imperial ministry are thereby fulfilled after the expiration of a certain period.

He concluded his argument by saying that if Russia did not ratify the treaty, the disputes over the area would assume important proportions and it would be impossible to foresee the end of them or their consequences. 1

Middleton had been aware that the expiration of article four would cause trouble. Writing to Adams on April 19, 1824, Middleton said:

It may possibly. . . be objected, upon a superficial view of the convention, that it surrenders a permanent right to a community of trade upon the northwest coast in exchange for a privilege which is to expire in ten years. In answer to this objection, I submit that this right must always have been held subject to extinguishment whenever the maritime domain, incident to actual occupation and settlement, shall be acquired by any nation upon those coasts; and I beg leave further to remark upon the same point, that I kept it always in recollection that when the stipulation of the fourth article, for liberty of trading with the natives, shall have expired by its own limitation, these coasts, insofar as they may then remain unoccupied, will fall into the general category of unoccupied places upon the coasts of the great ocean. ${ }^{2}$

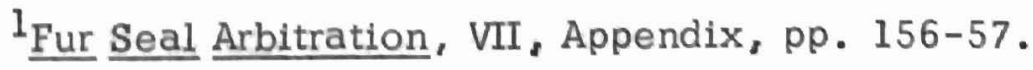

${ }^{2}$ Alaska Boundary Tribunal, II, 78-79. 
It can be seen from the above that there was no agreement between the negotiators regarding the effect of the expiration of article four. Nesselrode regarded the treaty as a compromise; that there would be no restrictions on American commerce for ten years, but after that period the United States would recognize Russia's exclusive jurisdiction over the northwest coast north of fifty-four degrees forty minutes. At that time no American would be allowed to visit the territory north of that line without Russian permission. Thus the expiration of article four would abrogate article one, and the Americans would have no rights in the area except those which the Russians might concede. I

The United States government viewed the treaty as merely a trading agreement. The United States agreed not to build any establishments north of fifty-four degrees forty minutes, but the question of a boundary was not settled; that nothing in the treaty could be construed as a final settlement of boundaries. ${ }^{2}$

The shareholders of the Russian-American Company were not convinced by the arguments put forth by their government for signing the treaty. Although they were unsuccessful in getting the treaty annulled, they were determined that no further concessions be made to the United

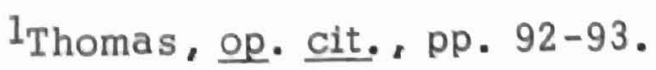

${ }^{2}$ Farrar, op. cit., p. 96. 
States after the expiration of article four. Since many of these shareholders were important people in Russia, the government had adopted their view by 1834. 1

${ }^{1}$ Mazour, op. cit., p. 309; Thomas, op. cit., pp. 94-95. 


\section{CHAPTER III}

\section{REOPENING OF THE TREATY OF 1824}

Article four of the Russian-American Convention of 1824 expired on April 17, 1834. At the time of the expiration, two American vessels were at the port of New Archangel. When told by the Russians that they no longer had a right to navigate in the waters of the Russian dominions, the American captains, Snow and Allen, said that they had not been informed of this by their government and intended to continue their voyage in Russian waters. To prevent this, Baron Wrangell, governor of Russian America, informed them by letter of the expiration of the fourth article of the 1824 treaty so that they could not justify themselves by pleading ignorance. Baron Wrangell's letter, dated April 27, 1834, read as follows:

Sir: As Governor of the Russian Colonies in America, and availing myself of your entrance into this port, I have the pleasure to inform you that--according to Art. IV of the Convention concluded and ratified by His Majesty the Emperor of all the Russias on one part, and on the other by the Highly Honorable The President of the United States of America, with the approval and consent of the Senate, on the 5/17 of April 1824--the right of frequenting the gulfs, straits, ports and bays included within the limits of the Russian possession on the North-West coast of America, namely: north of latitude $54^{\circ} 40^{\prime}$, has ceased for vessels of citizens of the United States of America, on the 5/17 of April of this year.

I consider it my duty to advise you of this fact in order to prevent any violation of the said Convention that might occur through ignorance of this circumstance and to beg you to communicate the contents of this note to all the citizens of the United 
States you may meet in these parts.

The copy of this circular shall be communicated to the United States Congress by the Russian Government.

I have the honor to be, \& $\mathrm{c}$.

(Signed)

Baron Wrangell, Captain of the Imperiod Russian Navy, Knight, Governor of the Russian Colonies in America.

The directors of the Russian-American Company reported this incident to Count Egor Frantsevich Kankrin, the minister of finance, and sent him a copy of Baron Wrangell's letter. They requested that Kankrin ask the American government make known to its citizens the expiration of the fourth article of the treaty. 1

In March, 1835, Baron Wrangell instructed Lieutenant Zarembo, commander of the Russian brig Chichagov, to station his ship in areas where foreign vessels were likely to visit on the northwest coast of America, and to demand that these vessels leave Russian possessions. He was told to aid any vessel whose captain claimed could not leave due to repairs being needed or for reasons of bad weather. If any captain of a foreign vessel refused to leave, Zarembo was instructed not to use force but to report the incident to the colonial authorities. If, however, such a vessel took violent action, Zarembo was given the authority to use military measures to punish the offender, a vessel

1 Alaska Boundary Tribunal, II, 232-33. 
taken under such circumstances being a legal prize. 1

The Russian minister in the United States, Baron de Krudener, on May 31, 1835, wrote to Mr. Dickens, who was in charge of the State Department during the absence of Secretary of State John Forsyth, telling him what had occurred on the northwest coast during the previous year. He asked that the United States government inform the American public about the expiration of article four of the treaty of $1824 .^{2}$

Dickens acknowledged the receipt of Krudener's note on June 3 , and said that he would submit it to the President. 3

Forsyth returned to his post shortly thereafter and wrote Krudener, on June 24, that the motives which led to the adoption of article four in 1824, still existed in equal force, and as the treaty proved to be beneficial to both countries, the President preferred not to take any steps to interrupt the commercial intercourse between the United States and Russian America unless there was reason to believe that the Russian government would prefer not to renew the article. 4

${ }^{1}$ Ibid., II, 233.
${ }^{2}$ Ibid., II, 236.
${ }^{3}$ Ibid., II, 237.

${ }^{4}$ National Archives, Notes to Foreign Legations in the United States from the Department of State, 1834-1906: Russia (Washington: File Microcopies of Records in the National Archives, 1950), VI, No. 3, Forsyth to Krudener, June 24, 1835. This source will hereafter be cited as Notes to Russian Legation; Alaska Boundary Tribunal, II, 237. 
Baron Krudener, on July 11, declined to express an opinion on the result of an application by the American government to renew article four and again asked that the American public be informed in regard to its expiration. 1

Forsyth replied that a formal notice by the government was not considered to be necessary as all citizens of the United States were bound to know existing laws and their rights and obligations under existing treaties. Forsyth did say, however, that informal notice would be given to the press of Baron Wrangell's warning to the captains of American ships. He then requested information regarding the measures that the Russian government proposed to take on the northwest coast relating to the admission of American vessels to the waters of the Russian dominions. ${ }^{2}$

As promised, the following notice was published in the Washington Globe on July 22:

It will be recollected that a convention was concluded between the U. States and Russia in April, 1824, regulating various matters connected with the commerce and navigation of the two nations on the north west coast of America. By the fourth article it was stipulated that the ships of both nations might, during a term of ten years, frequent, without hindrance, the interior seas, gulfs, harbors and creeks of each nation on that coast, for the purpose of fishing and trading with the natives of the country. The ten years expired

\section{$1_{\text {Ibid. , II, } 238 .}$}

${ }^{2}$ Notes to Russian Legation, VI, No. 4, Forsyth to Krudener, July 21, 1835; Alaska Boundary Tribunal, II, 238. 
in April, 1834; and we understand that formal notice has been given, by the governor of the Russian colonies, to the masters of the American ships then trading there, that they could no longer claim, under the convention, the right of landing at all the landing places, without distinction, belonging to Russia on that coast. Those interested in the trade will not fail to observe, that, under the second article of the convention, it is necessary for all American vessels, resorting to any point on that coast, where there is a Russian establishment, to obtain the permission of the governor and commander. 1

Forsyth reviewed the recent correspondence between Baron Krudener and himself for William Wilkins, the American minister in Russia, and authorized him to enter into negotiations with the Russian government with the hope of renewing article four of the treaty. He warned Wilkins that the Russian-American Fur Company was probably the cause of the seeming reluctance of the Russian government to discuss the renewal of the article, and that he should discredit the views of the company by showing that representations growing out of private interests should always be viewed with great caution. He told Wilkins that if the Russians refused to renew the article, he should ask for precise information in regard to the measures the Russians proposed to take to enforce their claims on the northwest coast. Forsyth also sent Wilkins a copy of Middleton's despatch of April 19, 1824, giving his interpretation of the treaty of 1824.2 Forsyth said that the United States

${ }^{1}$ Niles' Register, XLVIII (August 1, 1835), 379; Alaska Boundary Tribunal, II, 240.

${ }^{2}$ See above, page 20. 
State Department considered this interpretation to be correct. 1

Forsyth's instructions did not reach it.St. Petersburg until September 5, at which time the Russian minister of foreign affairs, Count Nesselrode, was absent from the city. His temporary replacement, Prince Lieven, was unwilling to take the responsibility for any matter which could be postponed until Nesselrode returned. 2

Wilkins had the impression that the Russians believed that the reciprocal privileges secured by the fourth article of the treaty worked to the advantage of the Americans only, and that they welcomed its expiration. His impression was confirmed by a conversation with a St. Petersburg merchant who was an ex-director of the Russian-American Fur Company, but "whose commercial pursuits \& connexions are not such as to give him a leaning against the Americans."

According to this merchant, the Russian-American Fur Company had always been opposed to the principle of reciprocity in regard to

$1_{\text {National Archives, Diplomatic Instructions of the Department }}$ of State, 1801-1906: Russia (Washington: File Microcopies of Records in the National Archives, 1946), XIV, No. 4, Forsyth to Wilkins, July 30 , 1835. This source will hereafter be cited as Instructions; Alaska Boundary Tribunal, II, 239-40.

${ }^{2}$ Despatches, XIII, No. 11, Wilkins to Forsyth, Sept. 7, 1835; Alaska Boundary Tribunal, II, 241. 
trading privileges on the northwest coast, and that the Russian government agreed to the fourth article only to put the question at rest, but had no intention of ever renewing it. The reason for this was that the Americans far excelled the Russians in commercial enterprise and were able to secure the greater portion of all the furs of the region. Wilkins summed up the situation by saying: "It all amounts to this--In competition with us they lose--by our exclusion they may gain. " I

Nesselrode returned to St. Petersburg near the end of October. He received Wilkins on November 4 , to discuss the renewal of article four. Wilkins submitted to him the following proposition in behalf of the American government:

To renew the stipulations of the fourth Article of the Convention of the 5/17th of April 1824, between His Imperial Majesty, the Emperor of All the Russias and the United States of America, either for another term of ten years, or for an indefinite period. 2

Nesselrode responded by saying that he was under the impression that the Americans had never made any use of the privileges granted to them by the fourth article of the treaty of 1824 . Wilkins corrected him by pointing out that American ships frequented the northwest coast annually and often furnished the Russian settlements there with supplies, and, at times, relieved them of severe scarcities. He

${ }^{1}$ Despatches, XIII, No. 12, Wilkins to Forsyth, Sept. 19, 1835.

${ }^{2}$ Ibid., No. 14, inclosure, Wilkins to Nesselrode, Oct. 23/ Nov. 4, 1835; Alaska Boundary Tribunal, II, 242. 
also referred to the warning which had to be issued to the two American ships which were at New Archangel at the very time of the expiration of the ten years. ${ }^{1}$

Nesselrode also spoke of the objection of the Russian government to Americans trading firearms and spirituous liquors to the Indians of the northwest coast in violation of the fifth article of the treaty of 1824. To this Wilkins answered that the treaty had put an end to such traffic, and there had been no violations since its adoption, or, in any event, there had been no complaints of that nature made to the United States government. ${ }^{2}$

The next day, Wilkins supported his argument on this point by sending Nesselrode a copy of a law, passed by the United States Congress in 1828 , which provided for the punishment of those who violated that article:

Be $\underline{\text { it enacted }}$ by the Senate and House of Representatives of the United States of America in Congress assembled, That if any one, being a citizen of the United States, or trading under their authority, shall, in contravention of the stipulations entered into by the United States with the Emperor of all the Russias, by the fifth article of the treaty, signed at St. Petersburg, on the seventeenth day of April, in the year of our Lord one thousand eight hundred and twenty-four, sell or cause to be sold, to the natives of the country on the northwest coast of America, or any of the

${ }^{1}$ Despatches, XIII, No. 14, Wilkins to Forsyth, Nov. 23, 1835.

${ }^{2}$ Ibid. , No. 14, inclosure, Wilkins to Nesselrode, Nov. 1/13, 1835; Alaska Boundary Tribunal, II, 243. 
islands adjacent thereto, any spirituous liquors, fire arms, or other arms, powder or munitions of war of any kind, the person so offending shall be fined in a sum not less than fifty nor more than two hundred dollars, or imprisoned not less than thirty days, nor more than six months.

Sec. 2. And be it further enacted, That the superior courts in each of the territorial districts, and the circuit Courts and other courts of the United States, of similar jurisdiction in criminal causes, in each district of the United States, in which any offender against this act shall be first apprehended or brought for trial, shall have, and are hereby invested with, full power and authority to hear, try and punish, all crimes, offences and misdemeanors, against this act; such courts proceeding therein in the same manner as if such crimes, offences and misdemeanors, had been committed within the bounds of their respective districts.

Approved, May 19, 1828.1

Nesselrode finally put Wilkins off by saying that since the

Russian-American Fur Company was particularly interested in the ques-

tion of the renewal of the treaty, he considered it his duty to consult

the directors of the company before he could give a final answer. ${ }^{2}$

Wilkins, in a note to Nesselrode dated November 13, voiced

his disapproval of allowing private interests to influence governmental

decisions:

It is not often that those who enjoy a monopoly under a liberal grant from an indulgent Sovereign will be willing, even to modify, or permit others to participate in, any portion of their privileges. But in the present instance it must be recollected such a

$\mathrm{l}_{\text {Ibid. , II, } 242 .}$

${ }^{2}$ Despatches, XIII, No. 14, Wilkins to Forsyth, Nov. 23, 1835. 
concession is not embraced in the proposition submitted without a fair equivalent; for the privilege to fish and traffick north and south of the latitude of $54^{\circ} 40^{\prime}$ would rest upon the just principles of reciprocity. I

In this same note, Wilkins called Nesselrode's attention to the first and eleventh articles of the Russian-American Commercial Treaty of December 18, 1832, intimating that those articles had a bearing upon the question of trade on the northwest coast. ${ }^{2}$ Wilkins later admitted, however, that those articles did not apply to the 1824 treaty. 3

Nesselrode replied to all of Wilkins' arguments with a short note on November 20 , saying that he was submitting the matter to the minister of finance, and, as soon as he had obtained the opinions of the proper authorities and the orders of the Emperor, he would give an answer. 4

Nesselrode wrote to the minister of finance, Count Kankrin, and told him of the American proposals to renew the fourth article for an additional ten years. He asked for a decision from Kankrin and, if that decision was against renewing the article, he asked if he could be

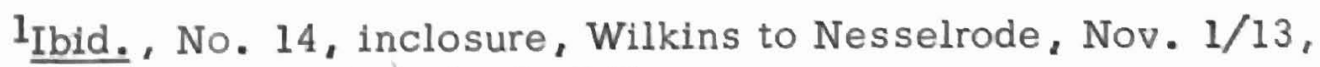
1835; Alaska Boundary Tribunal, II, 243.

${ }^{2}$ Ibid., No. 14, Wilkins to Forsyth, Nov. 23, 1835.

${ }^{3}$ Ibid., No. 16, Wilkins to Forsyth, Dec. 11, 1835.

${ }^{4}$ Ibid. , No. 14, inclosure, Nesselrode to Wilkins, Nov. 8/20, 1835; Alaska Boundary Tribunal, II, 244. 
furnished with information regarding steps the Russians were taking on the northwest coast due to the altered situation there, so he could communicate them to the American government as Wilkins had requested. I

The board of directors of the Russian-American Company gave their opinion on the subject in a report to the Department of Trade and Manufactures. After complaining of American violations of the fourth and fifth articles of the treaty, the directors declared:

- . that the acceptance of new conventions from the United States. . to allow their captains to freely navigate our waters for the purpose of trading in our possessions, will be decidedly prejudicial to the Russian American Company, but the permission for foreigners to come to the Port of Novo Archangelsk to trade with the office of the Company according to the instructions of the Governor, may remain as heretofore, and no new treaty is necessary for the same. 2

On December 7,1835, Wilkins held another conference with

Count Nesselrode. Wilkins had drawn up a new treaty, and he submitted

it to Nesselrode. It read in part:

Art. I. The provisions of the fourth article of the convention, concluded between the United States of America and His Imperial Majesty the Emperor of all the Russias on the 5th (17th) of April, 1824, shall be, and they are hereby, renewed and indefinitely extended and continued in force in the same manner as if all the provisions of the said article were herein specially recited.

Art. II. It shall be competent, however, to either of the high contracting parties, in case either should think fit, at any time

I Ibid. , II, 245-46.

2 Ibid. , II, 234-36. 
after the lst day of January, 1837, on giving due notice of twelve months to the other party, to annul and abrogate this convention, and it shall, in such case, be accordingly entirely annulled and abrogated, after the expiration of the said term of notice. 1

Nesselrode replied on November 28 (O.S.), that he could not give an answer until more information was received from the area concerned. He said that such information would not be received until the next spring when some of the officers from Russian America would be in Russia. One of these officers was Baron Wrangell, who was being called home in consequence of the Dryad affair. ${ }^{2}$

Wilkins reported these proceedings to Forsyth with the admission that his efforts to renew the fourth article of the treaty had been, for the present, unsuccessful. In this despatch, Wilkins gave Forsyth some facts regarding Russian America. He said that the chief post was New Archangel, where the Russian-American Company had a garrison of about seven hundred men, and had, altogether in Russian America, about two thousand people. ${ }^{3}$

I I $\underline{\text { bid. }, ~ I I, ~ 247-48 . ~}$

${ }^{2}$ Ibid., II, 248. See below, Chapter IV, in regard to the Dryad affair.

${ }^{3}$ Another source of this period stated that the Russian-American Company had twenty-six trading establishments in 1843, and its subjects consisted of 770 Russians, 1,442 creoles and 11,000 aborigines; "New Fields for American Commerce," De Bow's Review, IV (December $1847), 475$. 
Wilkins wrote that the Russian-American Company was not motivated by political considerations but was only interested in commercial gain and the elimination of all competition. "In a political point of view," he said, "the Russian possessions upon the American coast are not considered, in this Capital, as of any importance." According to Wilkins, the company based its claim to the privileges granted to it by the government on the grounds that Russia derived many advantages from the trade with China, the bringing of furs into Russia, the duties paid on these furs and the profits on the stock, which was held entirely by Russians, including the Emperor himself.

Wilkins also added that the Russians were not at all liked by the native Indians, who greatly preferred the Americans. ${ }^{1}$

Shortly after this, on December 24, Wilkins, who had requested to be recalled so that he might spend the winter in a milder climate, left Russia. The secretary of the legation, John Randolph Clay, was made charge' d'affaires. ${ }^{2}$

Clay reported in March, 1836, that Wrangell's arrival was still awaited, and nothing could be done until then. Clay's opinion was that Russia would not be easily persuaded to renew the fourth article but would claim sovereignty over the disputed area and an exclusive right to trade there.

${ }^{1}$ Despatches, XIII, No. 16, Wilkins to Forsyth, Dec. 11, 1835. 2 Ibid., No. 1, Clay to Forsyth, Jan. 14, 1836. 
Clay thought that the Russians would try to circumvent that part of the treaty which forbade American vessels from visiting occupied points on the coast by making only partial settlements. As an example, he pointed out that when the Russians prevented the British ship Dryad from entering the Stikine River in 1834, there was only a blockhouse at the mouth of the river. Clay said that the Russians could easily build a string of blockhouses along the coast and use them as evidence that they had settled the area. This is why Clay urged that the matter be settled as soon as possible and permanently. He feared that if the treaty were extended for another ten years, the Russians would do this and completely exclude the United States from the northwest coast after the treaty again expired. 1

But by this time, the matter was almost forgotten. Clay reported on September 2, 1836, that Baron Wrangell had arrived in St. Petersburg during the previous month. Clay wrote that he had not said anything to Count Nesselrode due to the fact that he had not received any instructions to continue the negotiations. ${ }^{2}$ It was to take new instructions, a new American minister and an incident on the faraway northwest coast of America to again revive the controversy.

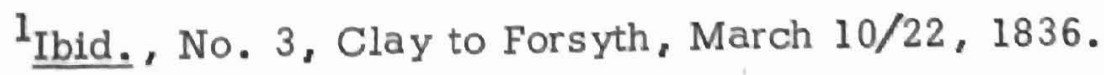
${ }^{2}$ Ibid., No. 12, Clay to Forsyth, Aug. 21/Sept. 2, 1836. 
The new minister, appointed to succeed Wilkins, was George Mifflin Dallas. Forsyth sent him instructions relating to the renewal of article four of the treaty in April, 1837, before Dallas had left the United States.

Forsyth reviewed the matter and told Dallas how Nesselrode had postponed an answer to the American propositions until the arrival of some officers of the Russian-American Fur Company from the northwest coast. It had, by this time, been several months since these officers had arrived, but no answer had been received.

Dallas was instructed to again bring up the subject but, this time, not to ask for information about the steps the Russians were going to take which would apply to American vessels frequenting the Russian settlements on the northwest coast. Forsyth thought that such an inquiry should be postponed until it could be ascertained that some measures had actually been adopted which would interfere with American intercourse with the Russian possessions. I

Shortly after sending these instructions, Forsyth received a despatch from John C. Jones, the American consul in the Sandwich Islands, about an incident that had occurred on the northwest coast of America in 1836.

$1_{\text {Instructions }}$ XIV, No. 2, Forsyth to Dallas, April 19, 1837; Alaska Boundary Tribunal, II, 248-49. 
The American brig Loriot, captained by Richard D. Blinn, had sailed from the port of Oahu, in the Sandwich Islands, on August 22, 1836, bound for the northwest coast to procure provisions, and, also, Indians to hunt sea otters. The Loriot made the land called Forresters Island on September 14, and, on September 15, anchored in the harbor at Tuckessan, located at latitude fifty-four degrees fifty-five minutes north and longitude one hundred thirty-two degrees thirty minutes west. On September 18, an armed Russian brig arrived in the harbor at Tateskey, situated at latitude fifty-four degrees forty-five minutes north and longitude one hundred thirty-two degrees fifty-five minutes west. The following day officers from the Russian brig boarded the Loriot and ordered Captain Blinn to leave the Russian dominions. Blinn went on board the Russian vessel where the commander repeated the order to leave.

This same order was again given to Blinn on September 20 and 23, and, on September 25, the Loriot was boarded by the crews of two armed boats from the Russian brig and directed to proceed to the harbor of Tateskey.

Blinn had ignored all of these orders, but, on September 27 , the Russians again boarded his ship and compelled him to go to Tateskey. When, off Tateskey, bad weather threatened, Blinn asked the Russian commander for permission to enter the harbor there. This request was 
denied, and Blinn was again ordered to leave Russian waters. He finally abandoned his voyage and returned to the Sandwich Islands, where he arrived on November 1 , and lodged a protest with Jones. 1

Jones wrote that it was apparent that Russia was trying to claim exclusive jurisdiction over the disputed area and intended to enforce this claim. ${ }^{2}$

Forsyth informed Dallas of the incident and told him that the State Department had no maps which showed Russian establishments at the latitudes mentioned in Jones' despatch. He instructed Dallas to ascertain whether or not such establishments existed and, if they did, to complain of the proceedings in relation to the Loriot which were assumed to have been instigated by the Russian-American Fur Company without authorization from the Russian government. Dallas was told to say:

. . . the President cannot but regard this act as one of a most unfriendly character, as the United States have had no official or other notice of the existence of such establishments, and have not, although an application has long since been made for them, even been furnished by the Russian Government with the regulations, consequent on the expiration of the 4th article of the Convention proposed to be applied to American vessels resorting to Russian Settlements on that coast. ${ }^{3}$

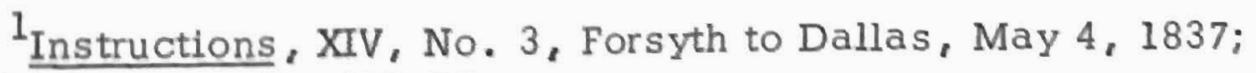
Fur Seal Arbitration, IV, 472-73.

${ }^{2}$ Thomas, op. cit., p. 99.

3Instructions, XIV, No. 3, Forsyth to Dallas, May 4, 1837. 
Forsyth then said if there proved to be no Russian settlements at the locations mentioned, then the outrage perpetrated on the Loriot would assume an even graver aspect, as it would be a violation of the right of American citizens to engage in lawful commerce on unoccupied coasts; a right which they had always exercised and which was secured to them by the laws of nations as well as by the first article of the treaty of 1824. Finally, Dallas was told to claim damages for the owners of the Loriot for the losses they had suffered. 1

Forsyth's instructions reached Dallas in London, where he immediately set to work looking for books, maps or charts in an unsuccessful attempt to find Tuckessan and Tateskey. ${ }^{2}$

After his arrival in St. Petersburg, in August, 1837, Dallas wrote Forsyth that he was hesitant to bring up the subject until he possessed more information. He said that he had started an inquiry in St. Petersburg in the hope that some Russian navy officers or some member of the Russian-American Fur Company might be able to tell him if there were settlements at Tuckessan and Tateskey. Dallas had the impression from Captain Blinn's protest that these settlements did exist, but he wanted to be sure before he began negotiations.

\section{${ }^{1}$ Ibid.}

${ }^{2}$ Despatches, XIII, No. 4, Dallas to Forsyth, June 27, 1837. 
Dallas then asked Forsyth how the American government interpreted the 1824 treaty. He said he had read Middleton's despatch of April 19, 1824, but was afraid that the Russians would say that the fourth article had settled the matter by giving Russia possession of the territory north of fifty-four degrees forty minutes and the United States possession of the territory south of that line. They might ask for what other reason the article was framed. ${ }^{1}$

Before Forsyth could answer, Dallas learned, from what he considered a reliable source, that there were no Russian settlements at the harbors of Tuckessan or Tateskey. He immediately sent a protest to Nesselrode saying that it was impossible to suppose that the treatment of the Loriot was sanctioned by the Russian government. He conveyed to Nesselrode the American construction of the treaty of 1824 without intimating the possibility of any other.

Dallas felt that even if the Russians claimed that there were settlements at the two locations, the treatment of Captain Blinn was so inhospitable that it would "present just the sort of occasion heretofore wanted for pressing the expediency of renewing the Fourth Article of the Treaty."2 Dallas ended his note to Nesselrode with a claim for

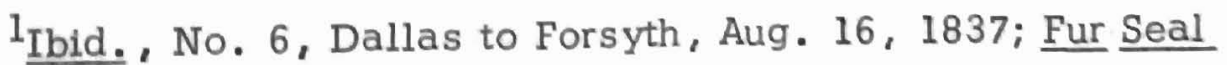
Arbitration, IV, 474-75.

${ }^{2}$ Despatches, XIII, No. 7, Dallas to Forsyth, Sept. 8, 1837. 
indemnification for the owners of the Loriot. 1

A short time later, Nesselrode left St. Petersburg making it impossible for Dallas to do anything further. On November 3, Dallas wrote that Nesselrode had been back for two weeks but had not returned to his duties. ${ }^{2}$

On that same day, Forsyth wrote Dallas regarding the American construction of the treaty of 1824. He explained that the first article only declared a right which both parties had possessed without treaty stipulations; to navigate and fish in the ocean along an unoccupied coast and to trade with the natives living on that coast.

The second article prohibited citizens of either nation from resorting to points occupied by the other, without permission.

The fourth article allowed citizens of either country to do all of these things at any point, whether occupied or not, for a period of ten years, after which, only unoccupied points were again open to citizens of both countries.

Forsyth pointed out that if article four was also to apply to unoccupied parts of the coast, as the Russians claimed, then this article would have merely provided for the temporary enjoyment of a privilege 1837.

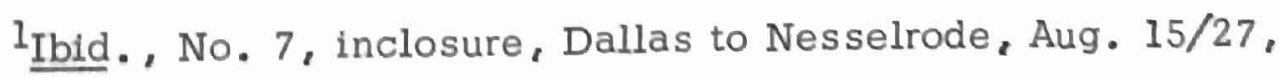
${ }^{2}$ Ibid., No. 9, Dallas to Forsyth, Nov. 3, 1837. 
which had existed in perpetuity and which had been declared to exist in the first article. If this were the case, then article four would contain no provision not already included in article one and would be of no effect.

But, if the fourth article would be construed to apply only to those parts of the coast which were occupied, it would then have taken effect as a temporary exception to the prohibition stated in article two, and the only result of its expiration would be a return to this prohibition.

Forsyth emphasized that the fourth article had to be taken in connection with the other articles of the treaty and could in no sense be construed so as to imply an acknowledgement on the part of the United States of the right of Russia to the possession of coast north of fifty-four degrees forty minutes:

The United States, in agreeing not to form new establishments to the north of $54^{\circ} 40^{\prime} \mathrm{N}$. made no acknowledgment of the right of Russia to the territory above that line. If such an admission had been made, Russia, by the same construction of the article referred to, must have acknowledged the right of the United States to the territory south of the designated line. But, that Russia did not so understand the article, is conclusively proved by her having entered into a similar agreement (1825) with Great Britain; and having, in fact, acknowledged in that instrument the right of possession of the same territory by Great Britain. 1

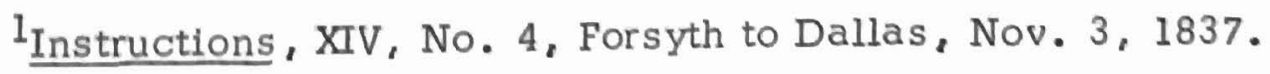


He concluded his argument by saying that the United States could only be considered to have acknowledged Russia's right to occupy new lands north of fifty-four degrees forty minutes, and even this was a mere matter of inference, as the treaty contained nothing more than a negation of America's right to occupy new points beyond that line. 1

Forsyth's despatch reached St. Petersburg on December 12 , by ordinary mail. Dallas wrote that since everything coming through the St. Petersburg post office was reportedly scrutinized by officials of the government, "your argument may probably produce its best effect in silence, by precluding a pretension thus in advance repelled." 2 Nesselrode resumed his duties on December 27.3 The next day Dallas sent him a note reminding him that he had promised an answer, in his letter of November 28, 1835, to the American propositions to renew article four, but that no such answer had ever been received. 4

When he did not receive an answer to this note, Dallas again wrote Nesselrode on January 9, 1838, this time, requesting an interview.

$1_{\text {Ibid. }}$

${ }^{2}$ Despatches, XIII, No. 12, Dallas to Forsyth, Dec. 25, 1837. ${ }^{3}$ Ibid., No. 13, Dallas to Forsyth, Jan. 14, 1838.

${ }^{4}$ Ibid. , No. 13, inclosure, Dallas to Nesselrode, Dec. 16/28, 1837. 
This request was granted, and the two men met on January 12 .

Dallas told Nesselrode that he had been in Russia for six months and that Nesselrode had been absent from St. Petersburg for five of those months. He asked if he could now have decisions from the Russian government regarding the Loriot affair and the renewal of the fourth article of the treaty of 1824.

Nesselrode replied that the letter about the Loriot had arrived while he was gone, and he would give an answer as soon as he had more information on the matter. As to the renewal of the fourth article of the treaty, Nesselrode said that he would be prepared to give an answer very soon. 1

Nesselrode's answer regarding the Loriot was dated February 23 (O.S.). He said that the Russian-American Company had been asked for detailed information on the incident but that the information had not yet been received. He continued, saying that it appeared, from the American version of the incident and from a deposition made by an officer recently returned from the northwest coast of North America, that in ordering Captain Blinn to leave Russian waters, the commander of the Russian brig did nothing more than conform to the instructions which were given him when the fourth article of the treaty expired. Nesselrode then said that the right to navigate freely in the

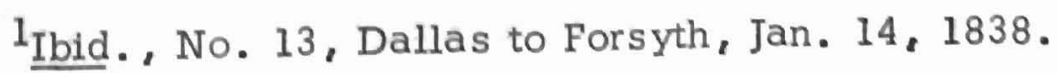


Pacific and to land on unoccupied shores, as granted by the first article of the treaty, was limited to a period of ten years by the fourth article. Since two years had passed after article four expired when the Loriot incident occurred, and proper notice of the expiration had been given, the Russian government could not be held responsible. 1

Dallas answered, in a letter to Nesselrode on March 17,2 saying that since the region concerned was remote and information from there difficult to obtain, that this was presumably the reason for the long delay in answering. But since the reply he received dispensed with the necessity for additional information and adopted the statement of facts derived from the American government, there would seem to be no reason for further delay.

Dallas reminded Nesselrode that in July, 1835, Secretary of State Forsyth had asked Baron Krudener to furnish the United States government with information regarding the measures the Russian government proposed to adopt in relation to the admission of American vessels to the northwest coast. Wilkins had repeated this request and Nesselrode had said that when officers from the area arrived in Russia in the spring of 1836 , such information would be communicated to the American

${ }^{I_{\text {Fur }}}$ Seal Arbitration, IV, 478-79.

${ }^{2}$ Despatches, XIII, No. 15, inclosure, Dallas to Nesselrode, March 5/17, 1838; Fur Seal Arbitration, IV, 480-85. 
government. Dallas said that this information had never been received, and, if it had, the unpleasantness resulting from the seizure of the Loriot could have been avoided:

And the President of the United States, unapprized of these regulations or of the particular points of the North-West Coast on which Russian establishments were newly formed, could not but view the abrupt proceeding, to which Captain Blinn was subjected, as an act, under any aspect, of the most unfriendly character. How far this sentiment will be changed or qualified by unexpectedly finding the slight on the American Flag and the armed opposition to American trade to have been ordered, and to be now sanctioned by the Government of His Imperial Majesty, upon the principles stated, the undersigned cannot venture to foresee.

Referring to the notice published in the Washington Globe on August 22, 1835, Dallas said that this notice contained no inhibition against voyages to the disputed area but specified that only places where there existed Russian settlements or landing places belonging to Russia were forbidden. Baron Krudener, who had insisted that the notice be published, took no exception to its phraseology. Also, only such points were included in Governor Wrangell's notice to the American captains.

Dallas then entered into a lengthy defense of the American construction of the treaty. His arguments were, for the most part, those that Forsyth had outlined in his despatch of November 3, 1837. About article four he said:

The view taken by His Excellency Count Nesselrode rests upon the provision. . . contained in the Fourth Article of the 
Convention. Of this it is essential to fix the true character. Does its limitation of ten years apply to the broad national right of resorting to unoccupied points of the coast? If it do [sic] not, the position taken is untenable. That it does not would seem to be a conclusion of the gravest as of the lightest scrutiny.

The renunciation of a prerogative so high and important, if designed, would not have been left to mere inference from a disjointed paragraph; but would have been distinctly expressed in immediate connexion with its first statement. No motive can possibly be assigned for permitting an intended abandonment of such a right, formally declared in the First article, to lurk unseen in the varied language of the Fourth article.

The letter was concluded with a request to reconsider the grounds upon which the claim of the owners of the Loriot was dismissed.

This exchange with Nesselrode was reported to Forsyth. Dallas suspected that Nesselrode himself was not in favor of putting on the treaty the construction he had since asserted but was overruled by his ministerial colleagues. Dallas also thought it was possible that Nesselrode was merely trying to prepare the United States for some terms on which they would be willing to renew the fourth article. He thought those terms might consist of dropping the claim for damages for the owners of the Loriot or a renunciation of trade with the natives of the northwest coast.

Dallas favored strong measures if the Russians did not reverse their decision:

A refusal to revise their decision, definitively communicated, would seem to invite the United States to the protection of their lawful commerce by forcible means:--an invitation which will not, 
I presume, however unwelcome, need to be twice repeated. 1

On March 21, Nesselrode communicated to Dallas the decision of the Russian government regarding the renewal of article four. The decision was against renewing the article.

Nesselrode said that the temporary provisions of article four had proved injurious to the Russian settlements on the northwest coast. He added, that foreign vessels constantly violated article five of the treaty be selling firearms and liquor to the natives of the region, and that the legislative' measures taken by the United States to prevent such violations were of no effect since the provision contained in article five, which forbade the detention and search of vessels for illegal goods, made it impossible to enforce such legislation.

Nesselrode concluded his note by saying that the regret of the Russian government caused by its refusal to renew the fourth article was diminished by the conviction that the United States would not derive any advantage from its renewal since never more than four American vessels per year visited the Russian possessions in the area. ${ }^{2}$

Dallas acknowledged the receipt of Nesselrode's note and asked for information on the regulations which would govern the

${ }^{1}$ Despatches, XIII, No. 15, Dallas to Forsyth, March 19, 1838. ${ }^{2}$ Ibid. , No. 16, inclosure, Nesselrode to Dallas, March 9/21, 1838. 
admission of American vessels to the Russian dominions. ${ }^{1}$

Dallas told Forsyth that the Russian refusal was not unexpected, and that even if they would have consented to discuss the matter, there would probably have been no agreement on the details of the renewal. Since, under the American construction of the treaty, it was lawful for American ships to visit unoccupied parts of the coast north of fifty-four degrees forty minutes, Dallas advised that it be ascertained where Russian settlements were supposed to be located and such locations checked to make certain of their existence:

And if we cannot spare one or two of our vessels of war to make a thorough examination of that coast, as well as to assert, in defiance of petty obstacles, the national right to trade freely upon unoccupied points, we must be content, however reluctantly, to take just such statements for information as it may please the Fur Company's officers and agents to give. ${ }^{2}$

Finally, Dallas wanted to know if the right under the laws of nations to trade on unoccupied coasts was so certain that it would be insisted on even at the risk of disrupting relations between the United States and Russia. ${ }^{3}$

On April 27 (O.S.), Nesselrode informed Dallas of the one regulation which the Russian government had adopted in relation to the

${ }^{1}$ Ibid., No. 16, inclosure, Dallas to Nesselrode, March 14/26, 1838.

2 Ibid., No. 16, Dallas to Forsyth, April 19, 1838.

3I Ibid. 
northwest coast. It was simply that American vessels were no longer to frequent the interior seas, gulfs, harbors and creeks, north of latitude fifty-four degrees forty minutes, and Russian vessels were not to visit like places south of that line. Thus the Russians demanded the total exclusion of American ships from Russian waters. I

Dallas reported this to Forsyth and advised that American citizens be warned to stay away from the area. He said that although this was supposed to apply only to occupied places, it was clear that the Russians meant all points on the coast north of fifty-four degrees forty minutes were forbidden to American ships, whether those points were occupied or not. 2

Nothing further was done at this time by the United States to advance its claims on the northwest coast. Dallas, at his own request, was recalled and the matter suspended.

${ }^{1}$ Ibid. , No. 17, inclosure, Nesselrode to Dallas, April 27(O.S.), 1838.

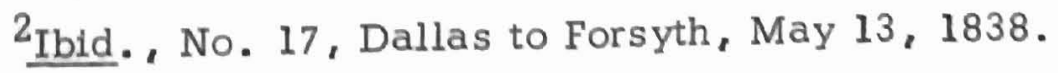




\section{AFTERMATH AND RESULTS OF THE NORTHWEST COAST DISPUTE}

During the time that the fourth article of the 1824 treaty was in force, the Russians made numerous complaints against the violation by Americans of the fifth article of the treaty, which forbade the sale of firearms, munitions, or liquor to the natives of the northwest coast. After article four expired, the mere presence of Americans, in what the Russians considered their territory, became the basis of protest, to be added to continuing complaints of violations of article five.

In 1829, a representative of the Hudson's Bay Company offered to supply the Russian colony in North America with English products at cost, products which, at that time, were being obtained from American traders. The Hudson's Bay Company said that because of Americans selling firearms and munitions to the natives, it was necessary to maintain large garrisons, at heavy expense, to guard stores, houses and hunting grounds. The exclusion of the Americans would bring benefits to both companies by relieving them of these extra

expenses. ${ }^{1}$ The offer was acknowledged by the Russian-American Company, but a decision was postponed indefinitely. ${ }^{2}$

1

${ }^{2}$ Ibid. , II, 262. 
Complaints against the Americans became frequent after the expiration of article four in 1834. The report of the board of directors of the Russian-American Company to the Department of Trade and Manufactures, in November, 1835, denounced the Americans at great length.

The report stated that even though Americans continued to navigate in Russian waters, there was no intention of using force against them. It said that even from 1824 to 1834 , when the Americans and English were allowed to visit the Russian possessions, it was necessary to avoid places where they were in order to avoid "disastrous consequences from competition in trade." It was claimed that the foreigners continually sold liquor, cannon, guns and powder to the Kolash, to whom they said that the Russians had no right to the territory and would enslave them. They usually treated the Russian authorities with hostility and suspicion. The report continued:

The Board of Directors deems it necessary to add that the American Captains made attempts, by converting the natives to Christianity, to bind them to them by means of religious ties; for this purpose missionary Green was brought there by Capt. Taylor of ship Volunteer. He might have succeeded in his undertaking, but the extreme greed of the Captain lost them the confidence of the natives and the missionary was obliged to return without having achieved any success. 1

In 1842 , the governor of the Russian colony informed his superiors that while on his tour of inspection he had come across

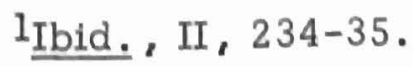


several American ships, believed to be whalers, and that he had been constantly receiving reports from various parts of the colony that American whalers had appeared in the neighborhood of the harbors and shores of the colony.

One of these reports was from Captain Kadnikov, commander of the company's ship Nasliednik Alexander. Captain Kadnikov stated that while on a voyage from Sitka to Okhotsk, he had hailed an American whaler, the captain of which informed him that he had come from the Sandwich Islands with thirty other ships to whale off the coast of Alaska and in the Aleutians, and that as many as two hundred whalers were coming from the United States during that year. The American captain also told him that the year before, in 1841, he had whaled in the same waters with fifty other ships, and that his ship had secured thirteen whales, from which were obtained sixteen hundred barrels of oil.

The company protested to the foreign office about the American intrusions, but the foreign office replied that they had no right to prevent American ships from taking whales in open sea, although these whalers were not allowed to visit the coast.

The company claimed, however, that these whalers often visited the coast where they carried on trade with the natives and often destroyed property belonging to both the natives and the company. 
The Russian-American Company considered the whalers such a nuisance that the governor of the colony in Russian America armed one of the company's ships to act as a cruiser to bar foreigners from the area. The company asked the Russian government that the cruiser be allowed to fly the flag of the Imperial Navy in order to command more respect. Permission was also asked to bar foreign whalers from within nine Italian miles of the coast.

The Russian government did not make a decision in regard to the company's ship flying the flag of the Imperial Navy. It warned the company of the importance of the armed cruiser exercising great caution in all matters concerning foreign ships. As to the barring of whalers from waters near the coast, the foreign office replied:

The fixing of a line at sea within which foreign vessels should be prohibited from whaling off our shores would not be in accordance with the spirit of the Convention of 1824 , and would be contrary to the provisions of our Convention of 1825 with Great Britain. Moreover, the adoption of such a measure, without preliminary negotiation and arrangement with the other Powers, might lead to protests, since no clear and uniform agreement has yet been arrived at among nations in regard to the limit of jurisdiction at sea. ${ }^{1}$

The foreign office did, however, notify the United States government of the establishment of armed cruisers to enforce the 1824 treaty. The United States made no protest and even agreed that the cruiser patrol

${ }^{I_{\text {Fur }}}$ Seal Arbitration, IV, 265-67, citing P. Tikhmenieff, Historical Review of the Formation of the Russian-American Company, and their Proceedings up to the Present Time (St. Petersburg: 1863), Part II. 
was a good idea. ${ }^{1}$ On September 26,1845 , the United States government had the following notice published in a Washington newspaper:

The Russian Minister at Washington has informed the Secretary of State that the Imperial Government, desirous of affording official protection to the Russian territories in North America against the infractions of foreign vessels, has authorized cruisers to be established for this purpose along the coast by the RussianAmerican Company. It is, therefore, recommended to American vessels to be careful not to violate the existing treaty between the two countries, by resorting to any point upon the Russian American coast where there is a Russian establishment, without the permission of the governor or commander, nor to frequent the interior seas, gulfs, harbors, and creeks upon that coast at any point north of the latitude of $54^{\circ} 40^{\prime} .{ }^{2}$

Following this, the United States made no further effort to protect its commercial rights on the northwest coast until 1850, when Secretary of State John M. Clayton tried unsuccessfully to revive Wilkins' argument that article one of the Commercial Treaty of 1832 was applicable to Russian America. ${ }^{3}$

The extended American attempts to renew the 1824 treaty brought out two important points. The first of these was that the Russian government attached no political importance whatsoever to their possessions in America. The fur trade was their only concern there and the Russian-American Company the key to the situation. The second was

1 Thomas op. cit., p. 107.

2Alaska Boundary Tribunal, II, 250.

${ }^{3}$ Thomas, op. cit. , p. 107; Notes to Russian Legation, VI, Clayton to Stoeckl, March 20, 1850. 
the fact that the American State Department held definite views of policy with regard to the Pacific coast, even at that early date. I

So far as can be determined, the United States never admitted Russia's sovereignty over the territory north of fifty-four degrees forty minutes. The Russians never yielded and the Americans seem to have acquiesed, but no retraction of the position taken by Forsyth and Dallas has ever appeared in the published diplomacy of the United States. The matter was not opened again, and, at the time of the purchase of Alaska, the subject was avoided, probably so that the title to the territory would not be clouded by a dispute over whether Russia had the right to sell what she did not own. 2

But regardless of Russia's insistence on her right to the northwest coast, it was obvious, by 1840 , that her interest in it was declining. It was in this year that Russia leased a large strip of their territory there to the Hudson's Bay Company. This arrangement ended a controversy between Russia and Great Britain that had begun several years earlier.

In 1833, the Russians founded a redoubt at themouth of the

${ }^{1}$ Victor J. Farrar, "The Reopening of the Russian-American Convention of 1824," Washington Historical Quarterly, XI (April 1920), 88.

${ }^{2}$ Farrar, "The Background of the Purchase of Alaska," p. 100. 
Stikine River, which they called St. Dionysius. The following year, a vessel of the Hudson's Bay Company, named the Dryad, appeared in sight of the redoubt and was boarded by a Russian officer who informed the captain that foreign vessels were no longer allowed to trade with the natives. The Dryad had on board a colony of settlers and supplies for the establishment of a trading post. The chief of the expedition, Peter Skeene Ogden, told the Russians that it was his intention to form an establishment some distance inland. It seems likely, however, that the Russians had previously heard that the English intended to form an establishment at the mouth of the river, which may have accounted for the founding of St. Dionysius. In any event, the Russians refused to allow the Dryad to proceed up the river, upon the ground that it would be a violation of the 1825 treaty, between Russia and Great Britain, which forbade British subjects to land at any place where there was a Russian establishment. The Dryad turned back, and the British government, on behalf of the Hudson's Bay Company, presented the Russian government with a demand for an indemnity of $\pm 22,150$ for losses sustained by the company due to the action of the Russian authorities. 1

There followed, between the two governments, several years of lengthy correspondence over the incident. Finally, to settle the matter, the Russians agreed to lease, to the Hudson's Bay Company,

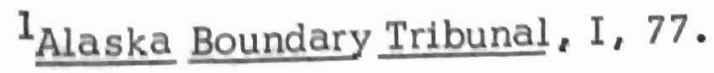


the entire mainland coast and interior country belonging to Russia between Cape Spencer, which formed the northwestern cape of the entrance to Cross Sound, and latitude fifty-four degrees forty minutes. In return, the British dropped their claim for damages in the Dryad affair and agreed to pay a fixed annual rental for the territory. I

Baron Wrangell met with George Simpson, one of the directors of the Hudson's Bay Company, in Hamburg, Germany, on February 1 , 1839. The lease was signed on February 6.2 This agreement was to take effect beginning June $1,1840 .^{3}$

As far as Count Nesselrode was concerned, the lease had two desirable objects in view. Writing to Count Kankrin in January, 1839, he said:

- . from a political point of view the wish to establish friendly relations with the Hudson's Bay Company through the lease of the. . territory, is in my opinion, worthy of the fullest consideration. In attaining this end we should gain the advantage of doing away with all rivalry in the fur trade and of putting an end to the frequent occasions of friction with the English and with the citizens of the United States of America which have already often led to unpleasant correspondence with those Governments.

This agreement would be especially desirable because it would enable us to avoid all further explanations with the Government of the United States as to its ceaseless demands, disadvantageous to our interests, for the renewal of Article IV of the

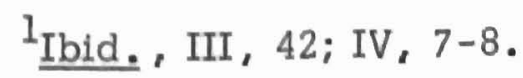

${ }^{2}$ Ibid., III, 43.

${ }^{3}$ Ibid., IV, 8. 
Treaty of 1824, which granted to American ships the right of free navigation for ten years in all the seas and straits, adjacent to our dominions on the northwestern coast of America. 1

The United States was at first disturbed by the lease which indicated possible British expansion. Even the Russian minister to the United States, Alexander Andreevich Bodisco, was opposed to the lease, because he feared that the United States would think that it had been kept out so that Great Britain could be let in. ${ }^{2}$ William Chew, the secretary of the American legation in St. Petersburg, thought that the main object of the lease was to excite American jealousy. ${ }^{3}$ But when convinced that it was only a lease, the United States made no further objection. 4

The lease of the territory to the Hudson's Bay Company marked the beginning of the wane of Russia's power in America. St. Dionysius became Fort Stikine. A year later, Fort Ross, in California, was sold to Sutter, and "the retreat of the Russian was well under way. " 5

I Ibid. , II, 312.

${ }^{2}$ Thomas, op. cit. , p. 107.

${ }^{3}$ Despatches, XIII, No. 5, Cambreleng to Forsyth, Sept. 30 , 1840.

${ }^{4}$ Thomas, 으. it., p. 107.

5 Clarence L. Andrews, "Russian Plans for American Dominion," Washington Historical Quarterly, XVIII (April 1927), 91. 
An interesting footnote to the entire Russian-American controversy over the northwest coast came to light some years later, during the time of the purchase of Alaska. During a discussion of Alaska, a member of Congress, Representative Benjamin Meyers, of Pennsylvania, I made the statement that the United States government, under the Van Buren and Polk administrations, had twice offered five million dollars for Alaska and had been refused. When asked for proof of this by Representative Williams of Pennsylvania, Mr. Meyers said that he had obtained that information from the state department.

This information was then confirmed by Representative Nathaniel C. Banks, chairman of the committee on foreign relations, in the course of the following conversation:

Mr. BANKS. If the gentleman from Pennsylvania will allow me, I will say that this Government has three times contemplated the purchase of Russian-America from the Russian Government; and twice it has made the offer of $\$ 5,000,000$, which has each time been refused.

Mr. WILLIAMS of Pennsylvania. Has the chairman of the Committee on Foreign Relations [Mr. Banks] furnished to the House and the country any evidence to this effect?

Mr. BANKS. I have not. But I understand that to be the fact, and I make the statement on my responsibility. Once during Mr. Polk's administration the matter was discussed, but terminated

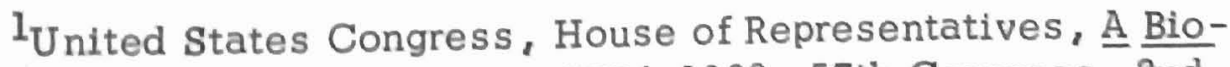
graphical Congressional Directory, 1774-1903, 57th Congress, 2nd Session, House of Representatives Document No. 458 (Washington: Government Printing Office, 1903), p. 692. 
without any formal offer or refusal. The offer, however, was made twice, once in $\mathrm{Mr}$. Van Buren's administration, and once in Mr. Buchanan's administration.

Mr. FERRISS [of New York]. I suppose the committee rely upon the authority furnished by the executive department. In Executive Document No. 177, a document furnishing the evidence in answer to a resolution of the House upon this subject, it is stated that Russia had twice offered this territory to the United States. But there is not one particle of evidence in that document that I can find that the Government of the United States ever applied to the Government of Russia for this territory. 1

Benjamin Platt Thomas confirmed this. He said that no documentary evidence could be found to substantiate the statement that the United States tried to buy Alaska at that time. ${ }^{2}$

Victor J. Farrar, however, called Banks a reliable witness whose word went unchallenged at the time. He also cited Cassius M. Clay as saying at the time of the purchase that the United States could have obtained Alaska from Nicholas I, but did not because of opposition from the slave interests who did not want to add a "free soil" territory to the country. Farrar also quoted Senator Charles Sumner as saying that he had heard that such an offer was made "as long ago as the Administration of Mr. Polk." Farrar concluded:

However much one is inclined to depreciate this data on the ground that it cannot be corroborated by papers in the Russian archives, one must agree that there was a desire on the part of

${ }^{1}$ United States Congress, Congressional Globe, 40 th Congress, 2nd Session, July 1, 1868 (Washington: Office of the Congressional Globe, 1868), Part 4, p. 3662 .

2Thomas, op. cit., p. 106. 
American statesmen to secure Alaska at this time. The matter may never have been the subject of a state paper, but it was certainly the subject of much verbal discussion, and many independent witnesses have knowledge of it. 1

The matter was, of course, settled by the purchase, by the

United States, of Alaska for the price of $\$ 7,200.000$, in 1867 .

${ }^{1}$ Farrar, "The Background of the Purchase of Alaska, pp. 100-02. 
CHAPTER V

OTHER RUSSIAN-AMERICAN CONTACTS

The controversy over the northwest coast of America was the only serious cause of friction between the United States and Russia during these years. Other contacts between the two countries were of a more friendly nature. American merchants, for example, found a market in Russia for a number of products.

The chief exports of the United States to Russia were raw cotton and tobacco. Also, it was American ships that carried nearly all of the sugar and coffee to Russia from Cuba. 1

A dispute arose in 1834 over the practice of the Danish government holding ships, bound for St. Petersburg and Riga with coffee and sugar, in quarantine for forty days. This affected mostly American ships, and the captains and owners of these ships protested this action due to the added expense it caused them. The American minister to Russia, William Wilkins, felt that the Danish government could have had no interest in such a protracted quarantine, and that this was done at the behest of the Russian government. ${ }^{2}$ Wilkins' protest to the Russian government resulted in the quarantine being modified to the extent that the ships' captains and merchants were satisifed. 3

${ }^{1}$ Despatches, XIII, No. 4, inclosure, Wilkins to Nesselrode, Dec. 29, 1834/Jan. 10, 1835.

2Ibid. , No. 2, Wilkins to Forsyth, Nov. 21, 1834.

3I Ibid. , No. 6, Wilkins to Forsyth, June 4, 1835. 
Wilkins wrote, in 1835, that the number of American ships destined for St. Petersburg that year would not exceed forty-five or fifty, while the usual average was about sixty-five. This was partly due to a decrease in the sugar trade. Sugar had previously been abundant, but had become scarce at this time, causing prices to rise. The cargoes of the American vessels arriving at St. Petersburg, in addition to carrying sugar and coffee from Cuba, carried American rice and cotton, dye woods, mahogany, indigo, gum, shellac and oak bark for tanning. Formerly, olive oil and rum were brought into Russia in considerable quantities, but the levying of high duties excluded them.

The importation of American cotton was increasing. In 1834, Russia imported 5,475,960 pounds of cotton from the United States, an increase of twenty per cent over 1832. The Russians were building plants to process cotton, and it was expected that the demand for American raw cotton would increase, while the demand for cotton twist from England would decrease.

Russia's exports to the United States at this time consisted of sailcloth and diaper, 1 of which the United States took three-fourths of Russia's total export, and also of feathers, hides, calfskins, cordage,

${ }^{l}$ Diaper was silken or linen cloth woven with ornamental devices or geometric patterns. 
bristles, quills, candles, copper and wool. I

Russian tariffs were a source of much annoyance to American merchants. The purpose of these tariffs was, for the most part, to encourage agriculture and industry in Russia. All goods which could be manufactured in Russia were barred from importation into the country or subjected to such high duties so as to deter anyone from importing them.

John Randolph Clay, secretary of the American legation in St. Petersburg, said, in 1837 , that this tariff policy caused the Russian public much needless hardship, because the goods manufactured in Russia were often inferior and usually far more expensive than the same articles would be if they were imported from abroad. Clay thought that foreign imports would benefit Russian industry by giving them competition which they badly needed. ${ }^{2}$

The tobacco trade with Russia generated much interest in the United States. Secretary of State Forsyth told the American minister, George Dallas, to determine whether or not the Russian tariff discriminated against American tobacco and, if it did, to try to remedy the situation. 3

${ }^{1}$ Despatches, XIII, No. 10, Wilkins to Forsyth, Sept. 1, 1835.

${ }^{2}$ Ibid., No. 21, Clay to Forsyth, Jan. 19/31, 1837.

${ }^{3}$ Instructions, XIV, No. 2, Forsyth to Dallas, April 19, 1837. 
Dallas made a study of this subject and said that the United States supplied Russia with half a million dollars worth of tobacco annually, and that this amount could be greatly increased if the tariff were modified. 1

According to Dallas, the consumption of tobacco in Russia, once capitally punished, had increased rapidly since the French invasion of 1812, and, by the 1830's, smoking and snuffing were common. The three tobaccos used in Russia were American, Turkish and Russian. The American was considered the best and was used for cigars and snuff. The Turkish was milder and was used in pipes. The Russian was considered poor in all respects.

Very little of the American tobacco came directly from the United States; most of it came through Europe. The Turkish tobacco came direct but in insufficient quantities, and it was usually adulterated with Russian tobacco. Dallas believed that if the United States could send enough tobacco and send it direct, they could keep the Turkish out and stop the growth of the Russian. But he added, that the consumption of tobacco was increasing so fast that he doubted whether the United States could ever supply enough.

The Russians, at this time, grew about one million poods ${ }^{2}$

${ }^{1}$ Dallas, op. cit. , p. 16.

${ }^{2}$ One pood equalled 36.07 pounds. 
of tobacco annually. It sold for seven or eight rubles per pood, while the American tobacco sold at forty to fifty rubles per pood. The Russians imported 1,798,020 pounds of American tobacco in 1833,2,245,752 pounds in $1834,2,328,408$ pounds in 1835 and $2,849,544$ pounds in 1836 .

Dallas reported that of all the tobacco imported into St. Petersburg during 1837, only one shipment had come directly from the United States. The rest of the shipments, over forty of them, came from various parts of Europe.

The purpose of the high Russian duty on American tobacco was to force people to smoke Russian tobacco. Dallas suggested that the United States might compel reciprocity by treating Russian exports to the United States in a similar way. Russian exports to the United States from 1833 to 1836 had a total value of eight million dollars, and Dallas thought that a tariff on those goods might make them relax the tariff against American tobacco. 1

During the year 1837, for example, forty-four American vessels arrived in St. Petersburg, Of these, twenty-one came directly from the United States. Their cargoes consisted of $10,840,763$ pounds of white sugar, 775,447 pounds of coffee, 849,279 pounds of cotton, 282,897 pounds of rice, 116,302 pounds of indigo, 10,313 pounds of tobacco,

${ }^{1}$ Despatches, XIII, No. 8, Dallas to Forsyth, Oct. 6, 1837. 
93,352 pounds of pepper, 8,885 pounds of hops, 18,471 pounds of shellac and 4,800 pounds of raisins.

Twenty-one of the vessels came from Havana carrying $18,351,289$ pounds of white sugar, 573,000 pounds of coffee and, also, a large number of cigars. One vessel came from Bremen carrying 89,218 pounds of white sugar and 19,224 pounds of coffee. The other ship came from Antwerp laden with 478,260 pounds of sugar, 38 parcels of machinery, 15 cases of books and a case of arms. 1

The Russians sold a variety of things to the United States. During the year 1840, Russian products exported to the United States included 189,085 poods of bar iron, 64,757 poods of sheet iron, 174,080 poods of hemp of various types, 56,720 poods of cordage, 4,085 poods of bristles, 11,390 poods of feathers, 3,237,298 arsheens $^{2}$ of diaper, 952,200 arsheens of crash, $314,935,000$ arsheens of quills and 41,082 pieces of sailcloth. 4

Russian exports to America were decreasing at this time. The reason for this was the high price of Russian produce and the small

${ }^{1}$ Ibid. , No. 12, Dallas to Forsyth, Dec. 25, 1837.

${ }^{2}$ One arsheen equalled twenty-eight inches.

${ }^{3}$ Crash was a coarse linen fabric which could be used for clothing or as a floor covering.

4"Commercial Statistics," (February 1841), 200. 
demand for it in America. ${ }^{1}$ Many American ships bringing products from the United States to Russia were forced to return without cargoes unless they could obtain them at ports in other European countries. ${ }^{2}$

American exports to Russia, however, continued to increase. A new Russian tariff law took effect on January 1, 1842. One result of the tariff was to increase the duty on tobacco. 3 The former duty on tobacco had been so high as to be almost a prohibition, and none at all had been imported from the United States during the year 1841.4 The new higher duty, however, did not seriously damage the American tobacco trade, as American tobacco had usually been imported into Russia through other places, mostly from Bremen. Agents of the Bremen manufacturing establishments in St. Petersburg bought the tobacco in Bremen and thus evaded the tariff. 5 The arrival at St. Petersburg, in 1845, of an American ship direct from Baltimore laden with tobacco, the first such direct shipment in several years, caused the American minister there, Colonel Charles S. Todd, to hope that it signaled the renewal of the tobacco trade in its direct form. 6

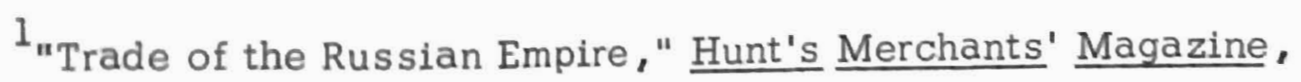
VII (September 1842), 224.

${ }^{2}$ Despatches, XIV, No. 31, Todd to Legare', June 6/18, 1843; Ibid. , No. 46, Todd to Calhoun, June 28/July 10, 1844.

${ }^{3}$ Ibid. , No. 5, Todd to Webster, Nov. 17/29, 1841.

4Ibid., No. 6, Todd to Webster, Dec. 10/22, 1841.

5Ibid. , No. 39, Todd to Upshur, Nov. 30/Dec. 12, 1843.

6 Ibid. , No. 63, Todd to Buchanan, Sept. 15/27, 1845. 
The chief American export to Russia during these years remained cotton. The duty on raw cotton was almost free. Colonel Todd wrote, in 1841 , that about three cargoes came annually from the United States and many more from Liverpool. Although the cotton from Liverpool came originally from America, many merchants preferred buying it at Liverpool in order to have a chance to make a better selection at one point. ${ }^{1}$

The new tariff of 1842 reduced the duty on raw cotton even further, while it increased the duty on cotton twist, which came chiefly from Great Britain. This was to result in an even greater demand for raw cotton from America. ${ }^{2}$ The purpose of the higher duty on cotton twist was to protect the Russian manufacturers of cotton fabrics.

Todd said, in 1843, that sixteen American ships entered the harbor at Kronstadt during the space of two days, most of them laden with cotton from America. ${ }^{3}$ The quantity of American cotton imported into Russia showed a sharp increase by 1845. In 1838, the amount had been $2,778,472$ pounds. In 1839 and 1840 , it dropped to $2,140,482$ pounds and 2,203,017 pounds respectively. ${ }^{4}$ During the year 1843, the Russians imported 3,150,680 pounds of American cotton. ${ }^{5}$ The next

I Ibid. , No. 5, Todd to Webster, Nov. 17/29, 1841. 2I Ibid., No. 31, Todd to Legare', June 6/18, 1843. 3 Ibid. , No. 32, Todd to Legare', June 19/July 1, 1843. 4"Trade of the Russian Empire," Hunt's Merchants' Magazine, p. 224 . 1845.

5Despatches, XIV, No. 61, Todd to Calhoun, Aug.29/Sept. 10, 
year the amount dropped to $2,638,080$ pounds, but the following year, in 1845 , it reached a new high of $6,992,818$ pounds. 1

There were many contacts between the Russians and the Americans in areas other than trade. Russia and America were both large developing nations, and it was only natural that Russia turned to America for help in such fields as railroad construction.

As early as 1834, Nicholas I had made known that he desired to build a railroad to connect Moscow and St. Petersburg. At this time, an Austrian named Anton von Gerstner was in Russia studying mines and manufacturing in the interior. He met with Nicholas early in 1835 and outlined a plan for a railroad network. Count Kankrin, the minister of finance, and a number of other important people in the Russian government were opposed to the project. Nicholas finally decided that Gerstner should start with a short railroad from St. Petersburg to the imperial residences at Tsarskoe Selo and Pavlovsk. ${ }^{2}$

The seventeen-mile line was opened in 1837, most of the financing having been furnished by British capitalists. 3 The tracks were raised above the level of the surrounding land to solve the problem

I Ibid. , No. 63, Todd to Buchanan, Sept. 15/27, 1845.

${ }^{2}$ Alexandre Tarsaidze, "American Pioneers in Russian Railroad Building, " Russian Review, X (October 1950), 287.

3 "The Railways of Russia," De Bow's Review, XV (September 1853), 279. 
of snow during the winter. The line was such a financial success that fares were soon reduced to less than half that of the horse-driven stage lines. 1

But the Tsar's chief interest remained the Moscow-St. Petersburg railroad. When Gerstner had first presented a plan for such a railroad, Nicholas had asked him if it was the shortest possible route. Gerstner told him that although it was not the shortest, it was the best considering the locations of the important cities to be touched by it. Nicholas then drew a straight line on a map connecting Moscow and St. Petersburg and told Gerstner to build it that way. The final result of this was to be one of the world's most perfect railroads, using only 405 miles of rail to cover 399 air miles.

Gerstner, however, was not to be the builder of this railroad. In 1838 , he went to America to study railroads there since that was a place where they were being built under conditions similar to those in Russia. On April 12, 1840, he died unexpectedly in Philadelphia. 2 In the summer of 1839 , two Russian engineers had been sent to the United States to study American railroads. They were Nikolai Osipovich Kraft and Pavel Petrovitch Melnikov. Both agreed that the

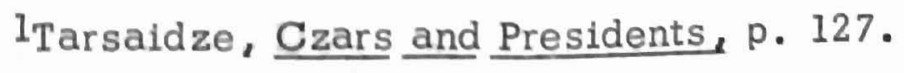

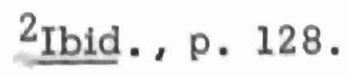


Moscow-St. Petersburg railroad was feasible and that it should be built. Both of these men took part in its planning and construction. 1

Melnikov later wrote that when he returned from America in September of 1840 , he was deeply convinced that railroads were necessary.for Russia; that they had been invented for Russia and America more than for the other countries of Europe. He felt that Russia's climate and vast expanses made railroads a special treasure for Russia as a means to shorten the distances and provide uninterrupted communication at all times of the year; in winter, when the waterways were closed by ice, and, in spring and autumn, when the roads were impassable because of the mud. 2

While in America, Kraft and Melnikov had been impressed by the work of a railroad engineer named Major George Washinton Whistler. When, in 1842, the Russians decided to go ahead with the construction of the Moscow-St. Petersburg line, Major Whistler was invited to come to Russia to supervise the work. He arrived in Russia in the summer of $1842 .^{3}$

Other Americans came to Russia to help with theproject. In

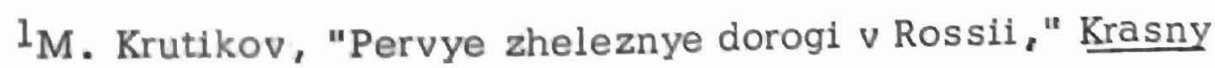
Arkhiv, LXXVI, No. 3 (1936), 154-55.

${ }^{2}$ M. Krutikov, "Nachalo zheleznodorozhnogo stroitelstva v Rossii," Krasny Arkhiv, XCIX, No. 2 (1940), 165.

${ }^{3}$ Tarsaidze, "American Pioneers in Russian Railroad Building," p. 289 . 
1842, Ross Winans of Baltimore had built a locomotive for the Russians which had greatly impressed them. The engine cost $\$ 11,500$ and was built for a track six feet in width. I Although unable to accept an invitation to go to Russia, his son, Thomas, went in his place. ${ }^{2}$ Others who went included Andrew Eastwick and Joseph Harrison, who were locomotive builders, and Thomas Winans' brother, William. ${ }^{3}$

A company was formed under the name of Harrison, Winans \& Eastwick, and it secured a contract to supply the railroad with 164 locomotives and 2,000 cars at a cost of five million dollars.

Actual work began early in 1843, and a factory was built at Alexandrovsky for the construction of locomotives and machinery. A machine-shop was also established at Kolpino, a few miles away. The Alexandrovsky works belonged to the Tsar and had some five hundred serfs attached to it. About two thousand more were eventually needed as the work progressed. At first, the managers and foremen were Americans or English, but as the Russians could be trained, they were given more responsibility. ${ }^{4}$

1The gauge finally decided upon for the Moscow-St. Petersburg railroad was 1.524 meters instead of six feet as had been used by Gerstner. Russian railroads have used that gauge ever since; Ibid. , p. 290.

${ }^{2}$ Niles' Register, LXIII (September 10, 1842), 32.

${ }^{3}$ Albert Parry, Whistler's Father (Indianapolis: Bobbs-Merrill Company, 1939), p. 90.

4Tarsaidze, "American Pioneers in Russian Railroad Building," pp. 191-92 . 
In 1847, the Tsar awarded Whistler the Cross of St. Anne, and his three associates, Harrison, Eastwick and Thomas Winans, were given rings worth over three thousand dollars. ${ }^{1}$ But Whistler did not live to see his railroad completed. On April 9, 1849, he died in St. Petersburg. At Whistler's death, the Tsar allowed no changes in the plan laid down by him, and hired another American army engineer, Major T. S. Brown of the Erie Railroad, to finish Whistler's work. ${ }^{2}$ When the line was opened in 1851, the trip from Moscow to St. Petersburg was cut from four days, travelling day and night, to just twentytwo hours. ${ }^{3}$

The Russian, interested in water transportation, turned to America for aid in this matter also. In 1839, two Russian naval officers visited the United States to study steam navigation on the Ohio and Mississippi Rivers. A Pittsburgh newspaper reported that their attention was attracted at that place by a snag boat, used for the removal of snags from the rivers. The Russians made a drawing of the boat, expecting that similar boats would be found useful on the Don, Volga and other Russian rivers. 4

${ }^{1}$ Parry, op. cit. , p. 286.

${ }^{2}$ Tarsaidze, "American Pioneers in Russian Railroad Building ," p. 294 .

${ }^{3}$ Ibid. , p. 292; "The Railways of Russia," DeBow's Review,p.280. ${ }^{4}$ Niles' Register, LVI (June 29, 1839), 288. 
The New York firm of William H. Brown constructed, for the Russian emperor, the frigate Kamchatka. It was built from a model furnished by two Russian naval officers, and, when launched in 1840, it was reported to be one of the finest war steamers afloat. 1

At the Russian Naval Academy, a large model of the President, an old American frigate, was taken apart and rebuilt every year by the senior cadets. Also, of the Russian navy's seventeen ships of the line in the Black Sea, nearly all had been built in New York at the docks of Eckford and Rhodes, and they were considered to be some of the best specimens of naval architecture in the world. ${ }^{2}$

Colonel Todd proudly reported that the official press of the Russian government frequently referred to the United States as a great maritime power. Todd suggested that some of the latest and most powerful American naval vessels should visit Russia. Besides enhancing American prestige, such a visit might have helped obtain even more orders for ships from American builders. ${ }^{3}$

Much of the information Americans had about the Russia of the 1830's and 1840's came from American diplomats stationed there. Most American diplomats did not like Russia but thought it a good place

${ }^{1}$ Ibid. , LIX (December 5, 1840), 213.

${ }^{2}$ Parry, op. cit. , p. 145.

${ }^{3}$ Ibid., pp. 145-46. 
to learn to be a better American. ${ }^{1}$ They tended to be skeptical of the veneer of civilization they found there. John Motley, later to become the distinguished historian of the Netherlands, and, at this time, Secretary of the American legation in St. Petersburg, while discussing Peter the Great, wrote:

He alone raised Russia out of the quagmire of barbarism, just as he raised St. Petersburg out of the morass; but it seems to me that just as this city may at any moment, by six hours' too long continuance of a southwest wind, be inundated and swamped forever, so may Russia at any moment, through a succession of half a dozen bad czars, be submerged in its original barbarism. 2

One of the more important of the American representatives in Russia during this time was George Mifflin Dallas, one of the few Americans who visited Russia twice in an official role; once in 1813, as Albert Gallatin's secretary, and again, from 1837 to 1839 , as minister to Russia. Prior to holding this post he had been mayor of Philadelphia and, from 1831 to 1833 , a United States Senator. He was to become Vice-President under Polk in $1844 .^{3}$

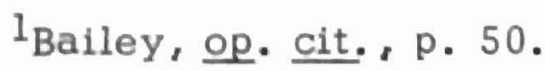

${ }^{2}$ John Lothrop Motley, The Complete Works of John Lothrop Motley: Correspondence, George William Curtis, ed. (New York: Fred DeFau \& Company, 1889), I, 124.

${ }^{3}$ William L. MacKenzie, The Life and Times of Martin Van Buren (Boston: Cooke \& Company, 1846), p. 297; Anna M. Babey, Americans in Russia, 1776-1917 (New York: The Comet Press, 1938), p. 4 . 
Dallas arrived at Kronstadt on Saturday, July 27, 1837. Niles' Register reported that when he was invited to be received by the Tsar at Peterhoff the next day, he appeared in ordinary clothes rather than his court uniform. When told that he could not be admitted, he departed refusing to don the court uniform, "avowing himself to be a democrat of the first water, and expressing some apprehension that it might impair his popularity at home." 1

Dallas gave an entirely different version of this incident. He said that the Tsar and Count Nesselrode had met him upon his arrival at Kronstadt and invited him to Peterhoff the next day. Immediately after Nicholas and Nesselrode departed, Dallas noticed that his court uniform was not complete. After seeing Nesselrode again and informing him of this, Nesselrode, after checking with the Tsar, told Dallas that it would be better to wait until the following Sunday to avoid being embarrassed in front of the diplomatic corps. ${ }^{2}$

During his stay in Russia, Dallas found few questions, other than the one concerning the northwest coast of America, to occupy his attention, and most of his time was spent "in a round of social gaiety. " 3

${ }^{{ } \text {Niles' }}$ Register, LIII (November 4, 1837), 147.

${ }^{2}$ Despatches, XIII, No. 5, Dallas to Forsyth, Aug. 2, 1837.

${ }^{3}$ Babey, loc. cit. 
Of Dallas' successors, Alexandre Tarsaidze had this to say:

But while Russian-American relations became more complex in the fields of commerce and industrial development, diplomatic relations were being casually fulfilled by a group of Ministers who were "neither very important in themselves nor left any worthwhile record of their experiences." I

Tarsaidze implied, as an example, that Colonel Todd's major achievement while minister to Russia was to get elected a member of the Imperial Agriculture Society. ${ }^{2}$ Even less could have been said about his immediate predecessor, C. C. Cambreleng, who served as minister to Russia during the years 1840 and 1841 .

It was true, however, that during much of this time, there was very little friction between the governments of the United States and Russia which would engage the attention of American diplomats. In 1841, John Motley wrote: "The relations between the United States and Russia are at present so completely settled that there is nothing at all to do." 3

Colonel Todd concurred when, in 1843, he wrote:

I am apprehensive that my communications may be destitute of interest or variety, but I am consoled with the reflection that the cause of their barrenness is a matter of congratulation--We have no

1Tarsaidze, Czars and Presidents, pp. 131-32.

${ }^{2}$ Ibid., p. 132.

${ }^{3}$ Motley, op. cit. , I, 104. 
subjects of collision with this Government--The path of duty is plain as well as pleasant. I have only to endeavour to maintain the good feeling long cherished for our Country. ${ }^{1}$

During most of this period, one Russian held the post of

Minister to the United States. He was Alexander Andreevich Bodisco.

He was appointed to this post in 1837, and he died in Washington on January 23,1854 .

On April 9, 1842, Bodisco, about sixty years old, married a sixteen-year-old American girl in a wedding which was the talk of Washington. It was attended by such people as President Van Buren, Senator Buchanan and David Farragut. Henry Clay gave the bride away. Bodisco later took his young bride on a trip to Russia where she created a sensation and was called by the Tsar "The American Swan." 2

Bodisco was one of the few foreign diplomats who actually liked Washington, D. C. He carried a heavy social burden there, having many parties and dinners. He was a wealthy man who had a quarter of a million dollars in American investments alone. ${ }^{3}$

Bodisco was held in very high esteem by nearly all who knew him. When his death was announced in the House of Representatives

${ }^{1}$ Despatches, XIV, No. 29, Todd to Webster, March 23/ April 4, 1843.

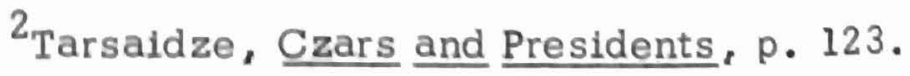

${ }^{3}$ Ibid. , pp. 119-20. 
in January, 1854, Thomas Hart Benton, then a congressman from Missouri, made a speech about him. Benton praised Bodisco, both personally and professionally. He also spoke highly of Tsar Nicholas I and of Russia's relations with the United States. Congress paid Bodisco the unusual tribute of adjourning for a day so that his many friends in that body could attend the funeral. ${ }^{1}$

${ }^{1}$ Congressional Globe, 33rd Congress, 1st Session, January 24, 1854 , p. 247 . 
SUMMARY AND CONCLUSIONS

The purpose of this thesis was to examine the relations between the United States and Russia between the years 1834 and 1845 . The only important diplomatic controversy during those years was in regard to American trading privileges on the northwest coast of North America.

This problem had its origin in the Russian-American Convention of 1824. Under the provisions of this treaty, the United States agreed not to occupy new points on the northwest coast north of latitude fiftyfour degrees forty minutes, and Russia likewise agreed not to occupy any point south of that line. The fourth article of that treaty allowed ships of either country to frequent any point on either side of that line, for purposes of fishing or trading with the natives, for a period of ten years. Whether these points were occupied by the other made no difference.

The controversy arose over the interpretation of the fourth article. The United States government viewed the treaty as a trading agreement and maintained that when article four expired, American ships would be barred only from places actually occupied by the Russians. There was to be no interference in regard to visits to unoccupied points north of flfty-four degrees forty minutes. The Russians, however, maintained that the expiration of article four gave them complete sovereignty 
over the territory north of that line.

When the fourth article expired in 1834, the Russians ordered all American ships to stay out of Russian waters. In 1835, the American minister in St. Petersburg, William Wilkins, submitted a proposal to the Russian government for the renewal of the fourth article of the treaty. The Russians made it clear that they were against any such renewal, but they put off giving an answer until they could consult with the Russian-American Fur Company, which controlled the Russian possessions in America and which was strongly opposed to any agreement which would allow the Americans to compete in the trade of the area. When Wilkins returned to the United States two years later, the matter was still not settled.

The dispute was reopened upon the appointment of a new minister to Russia, George M. Dallas, in 1837. The boarding of the American ship Loriot by the Russians and the expulsion of this ship from Russian America provided the reason Dallas needed to press the Russians for the renewal of the expired article.

After a period of evading the issue, the Russians finally refused to renew the article. The United States made no effort to resist this opposition to their trading privileges on the northwest coast, perhaps because President Van Buren felt that American trade in that region was not of sufficient importance. 1

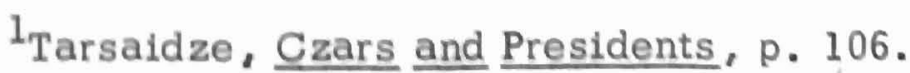


American traders, however, ignored the Russian prohibition, and they continued to violate what the Russians considered to be their territory. Russian protests of these violations continued until as late as 1845, when the American government, at the urging of the Russians, issued a notice to the American press warning American vessels to stay away from Russian settlements on the northwest coast north of fiftyfour degrees forty minutes.

In 1840, the Russians leased a large strip of their territory on the northwest coast to the English Hudson's Bay Company. This lease marked the beginning of the end of Russia's power in North America. The Russian government had never attached any political importance to their American possessions. Only the Russian-American Fur Company was interested in the area, and their only interest was of a commercial nature. It wanted foreigners kept out only to prevent competition in trade. The United States did not regain any rights in the area until it purchased Alaska from Russia in 1867.

American exports to Russia, despite obstacles in the form of regulations and tariffs, continued to increase during the 1830 's and 1840 's. The chief American exports to Russia were tobacco and cotton. Russia's exports to the United States decreased somewhat during this period due to the high prices of Russian goods and the decreasing demand for them in the United States. Russian exports to the United States 
included large quantities of iron and, also, hemp, which was highly prized by the American navy and merchant marine. ${ }^{1}$

Russia turned to America for help in solving her transportation problems. A number of Russians visited the U nited States to see how Americans built railroads and steamships. It was an American, Major George Whistler, who was in charge of the construction of Russia's first major railroad, from Moscow to St. Petersburg. Other Americans manufactured the locomotives and rolling stock used on this line. Also, many of Russia's finest naval vessels were built in the United States. From a diplomatic standpoint, the United States was represented in Russia during these years by many different men, most of whom were not of the highest caliber. Most of these men disliked St. Petersburg and had little to do there during their stays, most of which were of short duration. Russia, however, was represented in the United States by only one man during most of the years considered here.

The lack of serious problems between the two countries, especially after the suspension of the controversy over the northwest coast of America, resulted in a lack of diplomatic activity. There was not only a lack of friction, but even some matters where the two shared a common interest. It was evident that Russia cherished American friendship and considered the United States a bulwark against British power. Those

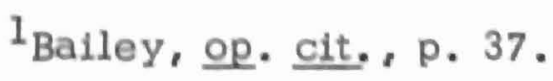


Americans who noticed this agreed that Russia identified her interests more closely with those of the United States than with those of any of the major European nations. This strange friendship, between two countries of such different ideologies, was to continue for many more years. 
BIBLIOGRAPHY 


\section{BIBLIOGRAPHY}

\section{A. MANUSCRIPT SOURCES}

Fur Seal Arbitration: Proceedings of the Tribunal of Arbitration at Paris. 15 vols. Washington: Government Printing Office, 1895.

National Archives. Diplomatic Instructions of the Department of State, 1801-1906: Russia. Washington: File Microcopies of Records in the National Archives, 1946.

National Archives. Notes to Foreign Legations in the United States from the Department of State, 1834-1906: Russia. Washington: File Microcopies of Records in the National Archives, 1950.

National Archives and Records Service. Despatches from United States Ministers to Russia, 1808-1906. Washington: National Archives Microfilm Publication, 1953.

Proceedings of the Alaskan Boundary Tribunal. 7 vols. Washington: Government Printing Office, 1903.

United States Congress. Congressional Globe. 46 vols., in 110. Washington: Office of the Congressional Globe, 1834-1873.

\section{B. BOOKS}

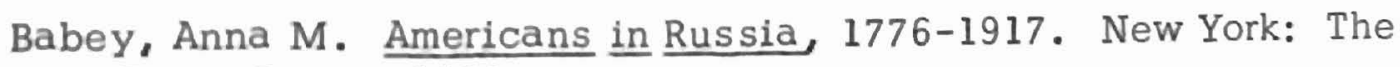
Comet Press, 1938.

Bailey, Thomas A. America Faces Russia. Ithaca, New York: Cornell University Press, 1950.

Dallas, George Mifflin. Diary of George Mifflin Dallas. Edited by Susan Dallas. Philadelphia: J. B. Lippincott Company, 1892.

Fremont, Jessie Benton. Souvenirs of My Time. Boston: D. Lothrop Company, 1887. 
Hildt, J. C. Early Diplomatic Negotiations of the United States with Russia. Johns Hopkins University Studies in Historical and Political Science, Series XXIV, Nos. 1-2. Baltimore: The Johns Hopkins Press, 1906.

Lyman, Theodore, Jr. The Diplomacy of the United States, 1778-1827. 2 vols. Second edition. Boston: Wells and Lilly, 1828.

MacKenzie, William L. The Life and Times of Martin Van Buren. Boston: Cooke \& Company, 1846.

Motley, John Lothrop. The Complete Works of John Lothrop Motley: Correspondence. Edited by George William Curtis. 3 vols. New York: Fred DeFau \& Company, 1889.

Parry, Albert. Whistler's Father. Indianapolis: Bobbs-Merrill Company, 1939 .

Perkins, Dexter. The Monroe Doctrine, 1823-1826. Harvard Historical Series, Vol. XXIX. Cambridge: Harvard University Press, 1932.

Powell, J. H. Richard Rush, Republican Diplomat, 1780-1859. Philadelphia: University of Pennsylvania Press, 1942.

Tarsaidze, Alexandre. Czars and Presidents. New York: McDowell, Obolensky Inc., 1958.

Thomas, Benjamin Platt. Russo-American Relations, 1815-1867. Johns Hopkins University Studies in Historical and Political Science, Series XLVIII, No. 2. Baltimore: The Johns Hopkins Press, 1930.

Tocqueville, Alexis de. Democracy in America. Edited by Richard D. Heffner. New York: The New American Library of World Literature, Inc. , 1956.

Tompkins, Pauline. American-Russian Relations in the Far East. New York: The Macmillan Company, 1949.

United States Congress, House of Representatives. A Biographical Congressional Dictionary, 1774 to 1903.57 th Congress, 2nd Session, House of Representatives Document No. 458. Washington: Government Printing Office, 1903. 
Williams, William Appleman. American-Russian Relations, 1781-1947. New York: Rinehart \& Company, 1952.

\section{PERIODICALS}

Andrews, Clarence L. "Russian Plans for American Dominion," Washington Historical Quarterly, XVIII (April, 1927), 83-92.

"Commercial Statistics," Hunt's Merchants' Magazine, IV (February, 1841), 193-200.

Farrar, Victor J. "The Background of the Purchase of Alaska," Washington Historical Quarterly, XIII (April, 1922), 93-104.

- "The Reopening of the Russian-American Convention of 1824 " Washington Historical Quarterly, XI (April, 1920), 83-88.

Krutikov, M. "Nachalo zheleznodorozhnogo stroitelstva v Rossii" (The Beginning of Railroad Construction in Russia), Krasny Arkhiv, XCIX, No. 2 (1940), 127-79.

- "Pervye zheleznye dorogi v Rossii" (The First Railroads in Russia), Krasny Arkhiv, LXXVI, No. 3 (1936), 83-155.

Mazour, Anatole G. "The Russian-American and Anglo-Russian Conventions, 1824-1825: An Interpretation," Pacific Historical Review, XIV (September, 1945), 303-10

"New Fields for American Commerce," De Bow's Review, IV (December, 1847), 475-86.

Niles' Register, August, 1835-September, 1842.

Tarsaidze, Alexandre. "American Pioneers in Russian Railroad Building," Russian Review, X (October, 1950), 286-95.

"The Rallways of Russia," De Bow's Review, XV (September, 1853), 279-81.

"Trade of the Russian Empire," Hunt's Merchants' Magazine, VII

(September, 1842), 205-24. 
APPENDIX 


\section{APPENDIX}

\section{RUSSIAN-AMERICAN CONVENTION OF $1824^{1}$}

In the name of the Most Holy and Indivisible Trinity: The President of the United States of America and his Majesty the emperor of all the Russias, wishing to cement the bonds of amity which unite them, and to secure between them the invariable maintenance of a perfect concord, by means of the present convention, have named, as their plenipotentiaries, to this effect, to wit: The President of the United States of America, Henry Middleton, a citizen of said States, and their envoy extraordinary and minister plenipotentiary near his Imperial Majesty: and his Majesty the emperor of all the Russias, his beloved and faithful Charles Robert, Count of Nesselrode, actual privy counsellor, member of the council of state, secretary of state directing the administration of foreign affairs, actual chamberlain, knight of the order of St. Alexander Nevsky, grand cross of the order of St. Wladimir of the first class, knight of that of the white eagle of Poland, grand cross of the order of St. Stephen of Hungary, knight of the orders of the Holy Ghost and of St. Michael, and grand cross of the legion of honour of France, knight grand cross of the orders of the black and of the red eagle of Prussia, of the annunciation of Sardinia, of Charles III. of Spain, of St. Ferdinand and of Merit of Naples, of the elephant of Denmark, of the polar star of Sweden, of the crown of Wirtemburg, of the Guelphs of Hanover, of the Belgic lion, of Fidelity of Baden, and of St. Constantine of Parma; and Pierre de Poletica, actual counsellor of state, knight of the order of St. Anne of the first class, and grand cross of the order of St. Wladimir of the second; who, after having exchanged their full powers, found in good and due form, have agreed upon, and signed the following stipulations:

Art. 1. It is agreed, that in any part of the Great Ocean, commonly called the Pacific Ocean, or south sea, the respective citizens or subjects of the high contracting powers shall be neither disturbed nor restrained, either in navigation or in fishing, or in the power of resorting to the coasts, upon points which may not already have been occupied, for the purpose of trading with the natives, saving always the restrictions and conditions determined by the following articles:

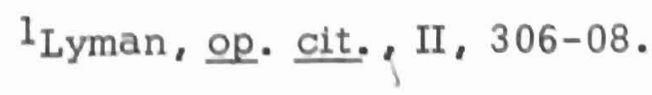


Art. 2. With the view of preventing the rights of navigation and of fishing, exercised upon the great ocean by the citizens and subjects of the high contracting powers, from becoming the pretext for an illicit trade, it is agreed that the citizens of the United States shall not resort to any point where there is a Russian establishment, without the permission of the governor or commander; and that, reciprocally, the subjects of Russia shall not resort, without permission, to any establishment of the United States upon the North West Coast.

Art. 3. It is moreover agreed, that, hereafter, there shall not be formed by the citizens of the United States, or under the authority of the said states, any establishment upon the Northwest coast of America, nor in any of the islands adjacent, to the north of fifty-four degrees and forty minutes of north latitude; and that, in the same manner, there shall be none formed by Russian subjects, or under the authority of Russia, south of the same parallel.

Art. 4. It is nevertheless, understood, that, during a term of ten years, counting from the signature of the present convention, the ships of both powers, or which belong to their citizens or subjects, respectively, may reciprocally frequent, without any hindrance whatever, the interior seas, gulfs, harbours, and creeks, upon the coast mentioned in the preceding article, for the purpose of fishing and trading with the natives of the country.

Art. 5. All spirituous liquors, fire arms, other arms, powder, and munitions of war of every kind, are always excepted from this same commerce permitted by the preceding article; and the two powers engage, reciprocally, neither to sell, or suffer them to be sold to the natives by their respective citizens and subjects, nor by any person who may be under their authority. It is likewise stipulated that this restriction shall never afford a pretext, nor be advanced in any case, to authorize either search or detention of the vessels, seizure of the merchandise, or, in fine, any measures of constraint whatever towards the merchants or the crews who may carry on this commerce; the high contracting powers reciprocally reserving to themselves to determine upon the penalties to be incurred, and to inflict the punishments in case of the contravention of this article, by their respective citizens or subjects.

Art. 6. When this convention shall have been duly ratified by the President of the United States, with the advice and consent of the senate on the one part, and on the other by his Majesty the emperor of all the Russias, the ratification shall be exchanged at Washington in 
the space of ten months from the date below, or sooner, if possible. In faith whereof, the respective plenipotentiaries have signed this convention, and thereto affixed the seals of their arms.

Done at St. Petersburg, the 17th (5th) April, of the year of Grace one thousand eight hundred and twenty-four. 